\title{
Recent Hydrophobic Metal-Organic Frameworks and Their Applications
}

\author{
Ruth Antwi-Baah ${ }^{1}$ and Heyang Liu ${ }^{1,2, * \mathbb{C}}$ \\ 1 School of Biological and Chemical Engineering, Zhejiang University of Science and Technology, \\ Hangzhou 310023, China; maadede97@gmail.com \\ 2 Zhejiang Provincial Key Lab for Chem. \& Bio. Processing Technology of Farm Product, \\ Hangzhou 310023, China \\ * Correspondence: heyang.liu@zust.edu.cn
}

Received: 12 October 2018; Accepted: 8 November 2018; Published: 12 November 2018

\begin{abstract}
The focus of discussion of this review is the application of the most recent synthesized hydrophobic metal-organic frameworks (MOFs). The most promising hydrophobic MOFs are mentioned with their applications and discussed. The various MOFs considered are sub-sectioned into the main application areas, namely alcohol adsorption and oil/water-alcohol/water separation, gas separation and storage, and other applications such as self-cleaning and liquid marbles. Again, the methods of synthesis are briefly described, showing how the features of the end product aid in their applications. The efficiency of the MOF materials and synthesis methods are highlighted and briefly discussed. Lastly, the summary and outlook section concludes the write-up giving suggestions that would be useful to present-day researchers.
\end{abstract}

Keywords: metal-organic framework; hydrophobicity; adsorptive separation; gas separation and storage; self-cleaning; liquid marbles

\section{Introduction}

Metal-organic frameworks (MOFs) are an attractive crystalline class of porous materials that entail metal ions and organic bridging ligands coordinated together in a controlled manner to enhance several requisite features over their conventional porous inorganic and organic counterparts such as activated carbons and zeolites [1-5]. These materials have gained enormous attention from various scientists around the world.

Over the years a vast variety of MOFs have been produced and have served diverse purposes in a wide range of industries. MOFs have attracted the attention of many scientists due to their large surface area, designable pore structure and functionality, high thermal stability and huge porosity $[1,6,7]$. These special properties have made them promising in diverse applications including gas storage $[8,9]$ and separation [10-13], chemical sensing [14,15], catalysis [16-20], wastewater treatment [21], proton conductors [22], and drug delivery [23]. Down the line, a disturbing problem was realized with these impactful materials upon their application in moisture-bound areas; most MOFs degrade under moisture conditions, limiting their functions in some industries [6,24].

Instability of MOFs is ascertained when the original structure of a MOF is distorted, and this is mainly realized by performing powder X-ray diffraction (XRD) and nitrogen sorption isotherms. With the sorption isotherms, the surface area of the MOF reduces and, with the XRD, the pattern of the peaks metamorphose or change [24].

It was reported that MOFs get degraded via two main mechanisms namely: (1) ligand displacement and (2) hydrolysis [25]. These mechanisms were arrived at through computational chemistry and confirmed experimentally. The ligand displacement occurs when a water molecule gets 
trapped into the metal-ligand $\mathrm{M}-\mathrm{O}$ bond of the framework leading to the formation of a hydrated cation and the release of a free ligand:

$$
\mathrm{M}^{\mathrm{n}+}-\mathrm{L}^{\mathrm{n}-}+\mathrm{H}_{2} \mathrm{O} \rightarrow \mathrm{M}^{\mathrm{n}+}-\left(\mathrm{OH}_{2}\right) \cdots \mathrm{L}^{\mathrm{n}-}
$$

On the other hand, in hydrolysis reaction, the metal-ligand bond is broken, and water dissociates to form a hydroxylated cation and free protonated ligand:

$$
\mathrm{M}^{\mathrm{n}+}-\mathrm{L}^{\mathrm{n}-}+\mathrm{H}_{2} \mathrm{O} \rightarrow \mathrm{M}^{\mathrm{n}+}-(\mathrm{OH})^{-}+\mathrm{HL}^{(\mathrm{n}-1)-}
$$

Conversely, hydrophobic MOFs possess water-resistant sites on their surfaces that curb this situation.

In the quest to curb this situation, another breed of MOFs known as hydrophobic MOFs have been synthesized by several scientists around the world. These MOFs have either highly strong metal-ligand bonds (which are difficult to hydrolyze) or contain organic struts that bear hydrophobic groups [26-31]. As the name implies, these are simply MOFs that repel water, thus, inhibiting the penetration of water molecules into their pores [26]. Hydrophobicity of MOFs is mainly classified by their contact angles with water. MOFs with contact angles (CAs) between $90^{\circ}$ and $150^{\circ}$ are referred to as hydrophobic, those with CAs greater than $150^{\circ}$ are termed superhydrophobic [30] and those with CAs much more above this figure are termed ultrahydrophobic [32].

In the past years, several hydrophobic MOFs were synthesized to solve the water-instability problem. The Cohen group, through postsynthetic modification (PSM), introduced hydrophobic alkyl chains on a series of Isoreticular metal-organic frameworks (IRMOFs) and MIL-53(Al)- $\mathrm{NH}_{2}$, rendering them hydrophobic and superhydrophobic respectively [30]. Another group complemented this work by directly synthesizing a series of highly hydrophobic Cu-based MOFs with novel perfluorinated aromatic linkers [31]. Kitagawa and coworkers devised an external-surface-corrugated superhydrophobic porous coordination polymer (PCP) with the use of aromatic hydrocarbon building unit [27]. Onwards, quite several hydrophobic MOFs, which are derivatives of some of the first works have been made by different researchers. Recently, a novel MOF called oCB-MOF- 1 whose crystal surface can be switched between hydrophobicity and superhydrophilicity by chemical treatment was reported [33]. Such switchable porous materials could be useful for obtaining smart porous surfaces such as membranes and coatings and serve a vast pool of purposes. Despite this, the direct application of many of such MOFs remains uninvestigated.

In addition, it is important to note that a group of scientists has recently produced a new method of activating open coordination sites (OCS) of MOFs, with the use of inert chloromethanes [34]. It is common knowledge that activation, that is, the removal of solvent molecules coordinated at the OCSs is a very essential step prior to the use of MOFs. The chemical activation method involving dichloromethane (DCM) [35] or trichloromethane (TCM) [36] was found to be a promising alternative to the conventional thermal activation (TA) method whereby the structural integrity of the framework is unpreserved in some cases [37-39].

In this review, we briefly present how some of the most recent hydrophobic MOFs by the manipulation of these two broad classes namely: (1) direct synthesis and (2) postsynthetic modification (PSM) were made, and their applications. The strategies and chemistry of postsynthetic modification will not be discussed here because it has been extensively discussed by some writers [40-43]. This rather short review is not intended to be all-inclusive in the entire body of published literature. Instead, we intend to mention several hydrophobic MOFs that have been employed in some application areas so far. We seek to bring to light the properties that these MOFs possess that make them function as hydrophobic particles, and hence their respective applications. Figure 1 shows the various applications discussed in the literature, thus, alcohol adsorption and oil/water-alcohol/water separation; gas separation and storage; and other applications such as self-cleaning and liquid marbles. Moreover, a concise description of the synthesis of these materials is also given. After the introduction, we 
highlight the applications of hydrophobic MOFs section by section, indicating the important criteria for each application area. Lastly, we shortly present our view of the setbacks in this field of research and the possible way forward.

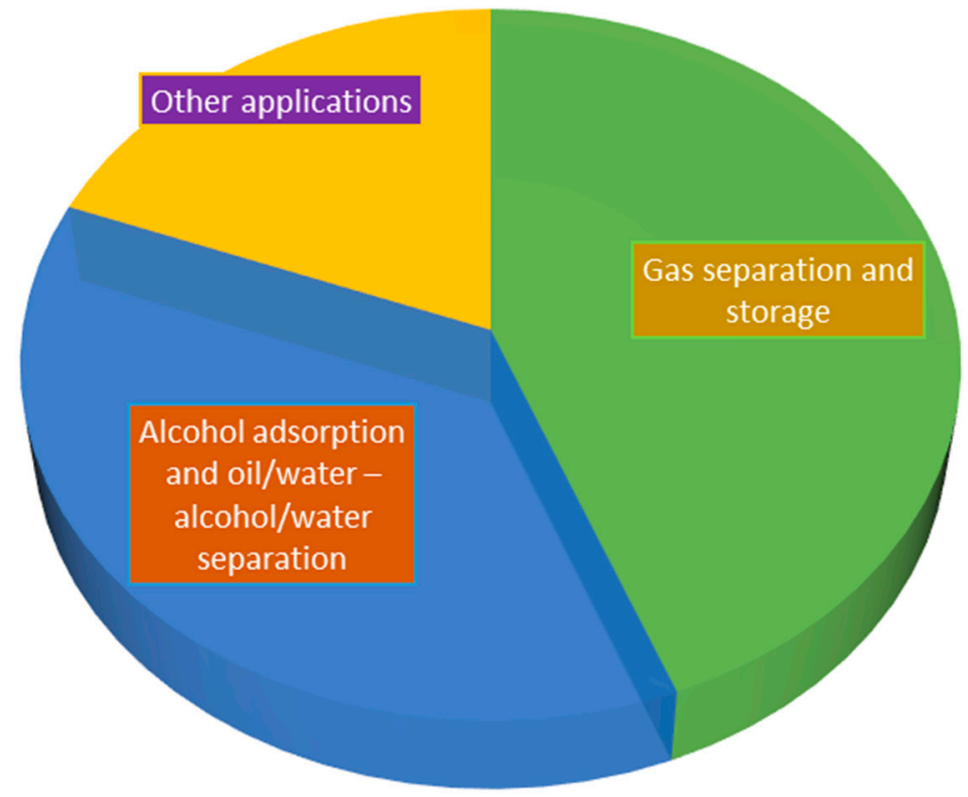

Figure 1. Pie chart describing the applications of hydrophobic MOFs presently.

\section{Alcohol Adsorption and Oil/Water-Alcohol/Water Separation}

The development of renewable and clean energy sources such as bioalcohols has attracted attention in recent years because of emerging scarcity of fossil resources and the accompanying critical environmental concerns [44]. Adsorptive separation by using porous materials is considered to be one of the most cost-effective and environmentally friendly methods of recovering bioalcohols from fermentation broth produced from biomass. The use of hydrophobic MOFs for adsorptive separation of alcohol/water mixture is a probable solution to this problem as they have a less strong affinity to water compared to other porous materials such as activated carbons, zeolites and polymeric resins which have as well been tested for this application [45-49]. Adjustable internal surface properties and tunable pore size $[50,51]$, and hydrophobicity $[45,52]$ are important criteria for the adsorption performances of such materials.

Moreover, hydrophobic MOFs for this same common reason of moisture stability hold promise for oil/water separation compared to other porous adsorbent materials such as organoclays, zeolites, activated carbons, sand and cotton fibers which have been used to tackle oil spillage [53-55]. Furthermore, fabricated functional materials are significant for preparing efficient oil-absorbing materials such as microporous polymers [45], macroporous gels [56], cross-linked polymer gels [57], meshes/membranes [58], sponges [59] and graphene [60]. This points out the necessity of the use of hydrophobic MOFs to solve such problems. Wettability of surface area, water resistance, and aqueous stability are the most important criteria for this application.

The exterior of hydrophobic surfaces and in many cases superhydrophobic surfaces have low surface energy [61,62] which is a phenomenon of superhydrophobic (SH) MOFs. Alcohol adsorption from aqueous solution is one essential application area for such materials. Liu et al. fluorinated Zeolitic Imidazolate Framework, ZIF-90 through an amine condensation reaction with pentafluorobenzylamine [63]. This type of post-functionalization was possible due to the presence of aldehyde groups in the ZIF-90 framework (Figure 2), proved by X-ray photoelectron spectroscopy (XPS) and Fourier transform infrared (FT-IR) spectra. XRD proved that the morphology of the as-prepared ZIF-90 was maintained after fluorination. The reported CA as shown in Table 1 was $152.4^{\circ}$ which 
proved its hydrophobicity. It achieved a 98\% recovery of ethanol from an ethanol/water mixture within $20 \mathrm{~h}$ of contact whereas the unfluorinated or unmodified ZIF-90 adsorbed only 7\% of ethanol from a similar mixture. The superhydrophobic MOF exhibits high adsorptive separation qualities for the removal of other bioalcohols such as methanol, isopropanol and butanol as well as its mixtures (Figure 3a). Interestingly, the material can be regenerated by simple thermal regeneration under vacuum and is highly adsorptive even after five successive cycles. These qualities make this material suitable for recovery of bioalcohols from aqueous solution and can be employed commercially to produce biofuels.

Table 1. Properties of hydrophobic MOFs highlighting contact angle (CA), postsynthetic modification (PSM), SC (self-cleaning), pH stability range (SR), moisture stability (MS), thermal stability, ionic solution stability range (ISSR), Brunauer-Emmett-Teller (BET) surface area (SA) and n-octadecylphosphonic acid (OPA).

\begin{tabular}{cccccccccc}
\hline MOF & CA $\left(^{\circ}\right)$ & PSM & SC & pH SR & MS & TS & ISSR & $\begin{array}{c}\text { BET SA } \\
\mathbf{( m}^{\mathbf{2}} \cdot \mathbf{g}^{-\mathbf{1}} \mathbf{)}\end{array}$ & References \\
\hline SH ZIF-90 & 152.4 & Yes & - & - & Yes & Yes & - & 1182 & {$[63]$} \\
OPA-UiO-66 & 160 & Yes & - & $1-11$ & Yes & - & $1-2$ & 1068 & {$[62]$} \\
OPA-UiO-66-SO 3 H & $>150$ & Yes & - & $1-11$ & Yes & - & $1-2$ & 1148 & {$[62]$} \\
OPA-PCN-222 & $>150$ & Yes & - & $1-11$ & Yes & - & $1-2$ & 1618 & {$[62]$} \\
UHMOF-100 & 176 & No & - & - & Yes & Yes & - & 469.2 & {$[32]$} \\
NMOF-1 & 162 & No & Yes & $1-9$ & Yes & Yes & $1-4$ & - & {$[64]$} \\
UPC-21 & $\geq 145$ & No & - & - & Yes & - & - & 1725.1 & {$[65]$} \\
SH & $\geq 146$ & Yes & - & - & Yes & - & - & $\approx 1134$ & {$[66]$} \\
NH $_{2}$-MIL-125(Ti) & $\geq 146$ & Yes & - & - & Yes & - & - & $\approx 1587$ & {$[66]$} \\
SH ZIF-67 & $\geq 146$ & Yes & - & - & Yes & - & - & $\approx 1386$ & {$[66]$} \\
SH HKUST-1 & $\geq$
\end{tabular}

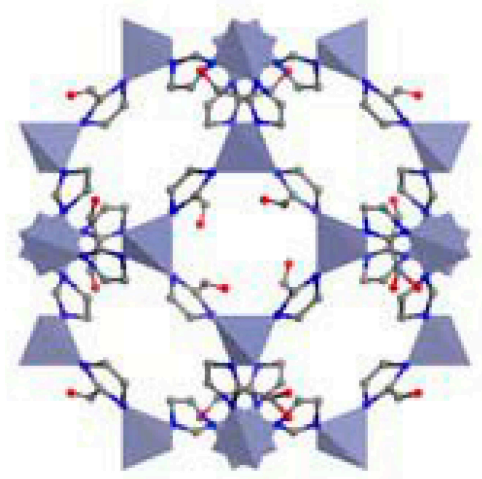

ZIF-90

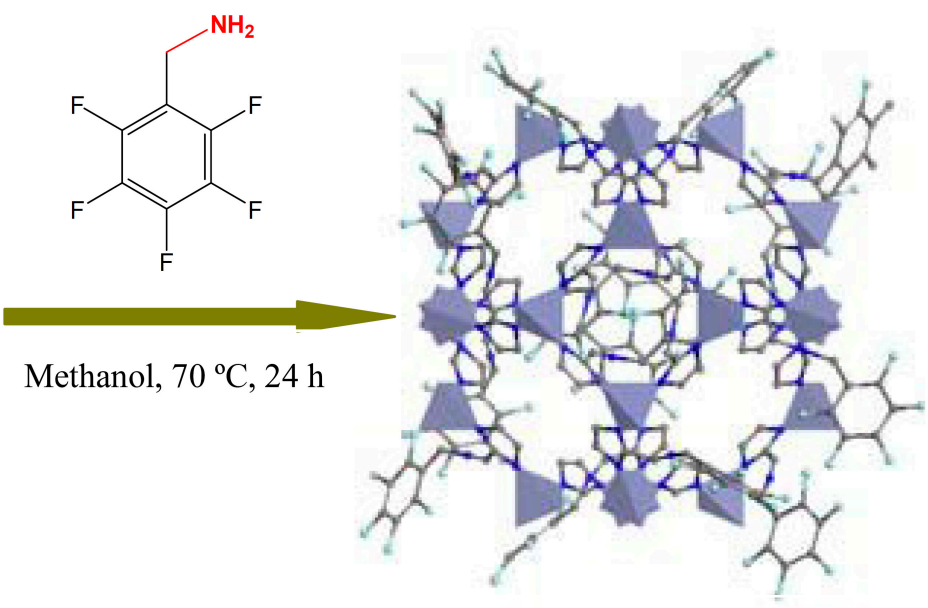

Superhydrophobic ZIF-90

Figure 2. Scheme of the synthesis of superhydrophobic ZIF-90 via an amine condensation reaction. Reprinted with permission [63] Copyright 2016, Royal Society of Chemistry. 


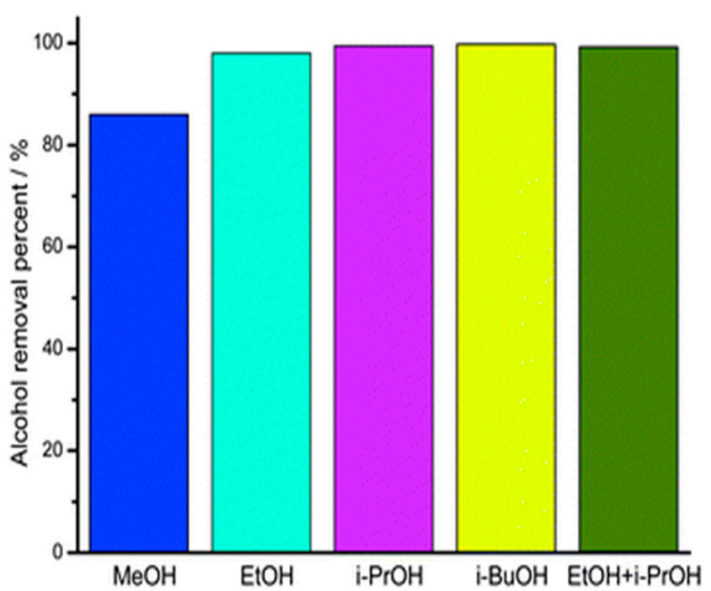

(a)

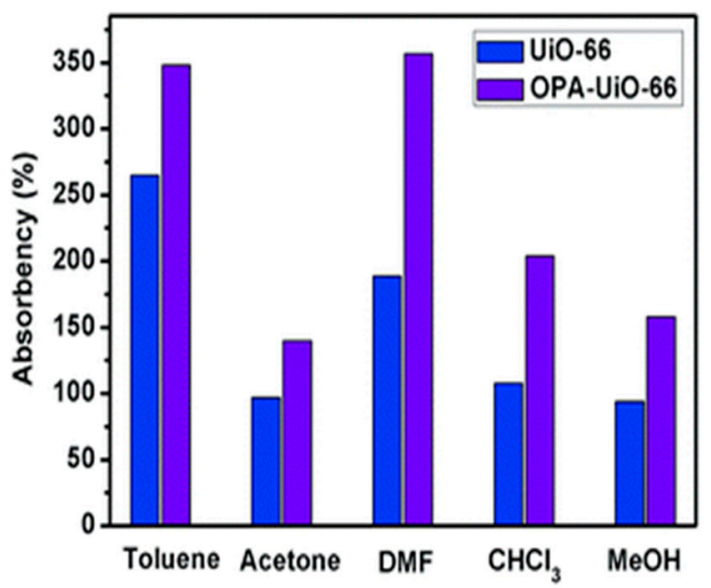

(b)

Figure 3. (a) Adsorptive separation performance of the superhydrophobic ZIF-90 for removal of alcohols from alcohols/water mixtures Reprinted with permission [63] (copyright 2016, Royal Society of Chemistry); (b) Absorption of organic solvents with UiO-66 before and after OPA modification. Reprinted with permission [62] Copyright 2017, Royal Society of Chemistry.

Recently, the Burg group presented a new method called nanomechanical mass correlation spectroscopy (MCS) [67] to measure the effective mass density of MOF nanoparticles in different solvent systems [68]. Three different MIL-101(Cr) MOF species were employed: MIL-101(Cr) nanoparticles and its derivatives functionalized at the coordinatively unsaturated metal sites with pyridine or pyrazine using postsynthetic modification [69]. MIL-101(Cr) with different inner pore functionalizations were suspended in binary mixtures of ethanol and water, and methoxyperfluorobutane (HFE-7100) and ethanol. Mass fluctuations resulting from the flow of this suspension through a suspended microchannel resonator were measured. The pyridine-modified MOF, which is more hydrophobic than the other two kinds, records a lower effective density in the polar mixture, which is probably due to increased ethanol content within the particles. It was said that this occurred because the particles aggregated with ethanol in the interstices and/or ethanol solvation layer was formed around the nanoparticles. The tuning of the inner functionalization of the MOF is also a contributing factor to this effect. The differences observed contribute new information about the specific interaction between the different solvent components and the internal surface. Again, the findings in this work show new opportunities for the use of MOF nanoparticles in the separation of solvent mixtures founded on the selective enhancement of a solvent component in the pores.

Oil/water and alcohol/water separation is another prime use of hydrophobic MOFs. Zhang et al. conducted a diauxic growth strategy on their previous MOF UPC-21 making it highly hydrophobic, with CA $145 \pm 1^{\circ}$ and exhibiting high oleophilicity [65]. The filtrate obtained from the initial MOF synthesis with the ligand $\mathrm{H}_{4} \mathrm{~L}$ and metal compound $\mathrm{Cu}\left(\mathrm{NO}_{3}\right)_{2}$ was further placed again in the same condition as the previous MOF to obtain highly hydrophobic UPC-21 with high yield. The main contributing factor to the hydrophobicity of this MOF was the intelligent choice of organic ligand $\mathrm{H}_{4} \mathrm{~L}$. It carries multi-aromatic hydrocarbon units in its pentiptycene core, which are hydrophobic and arranged in a 2D layer, and is the key reason for the hydrophobic behavior of UPC-21. It was used to separate water from several organic solvents and oils by simple filtration method and achieved approximately $99 \%$ separation efficiency. Figure 4 depicts how the separation was conducted. It is a promising material for oil recovery during the occurrence of oil spills. 


\section{Oil / Water Separation}

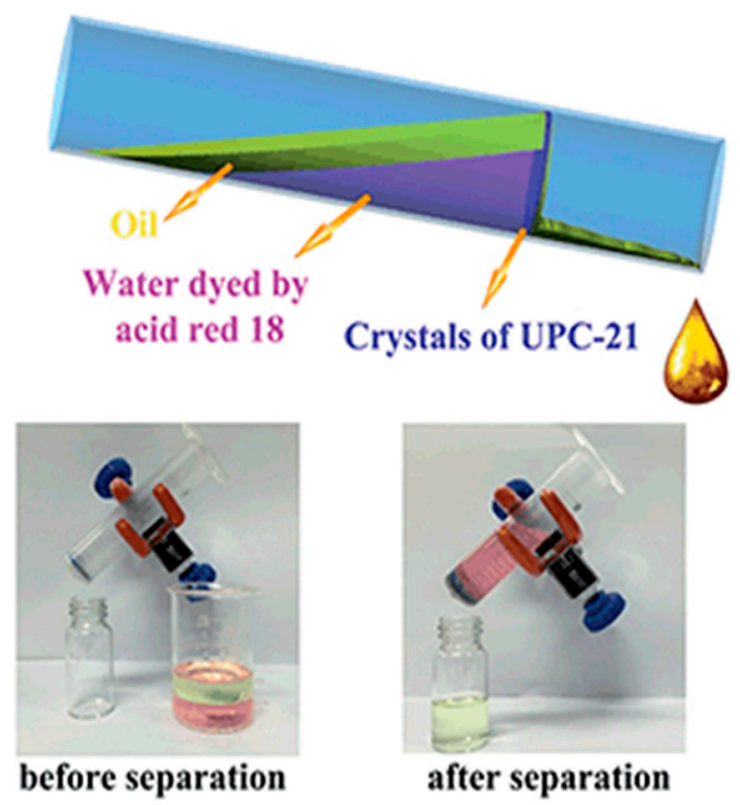

Figure 4. Photographs showing the status of separation experiments, oil/water separation efficiency. Water was colored with acid red 18 for observation. Reprinted with permission [65] Copyright 2016, Royal Society of Chemistry.

The organic linker component has an impactful influence over controlling the chemical and structural properties of the resultant material [3,70]. Hence, the systematic synthesis of new functionalized MOFs requires a meticulous choice of the organic linker component. In view of this, Mukherjee et al. synthesized an ultrahydrophobic MOF named UHMOF-100 with a careful choice of the organic ligand [32]. The new carboxylic low symmetry organic linker was cleverly synthesized, having in mind that such have a remarkable impact on the contact surface traits of the resulting material with liquid water [71]. The initial product formed, named UHMOF-100a contained dimethylformamide (DMF) guest molecules which were washed off to obtain UHMOF-100. Powder X-ray diffraction (PXRD) patterns show that the porous crystallinity and water stability of the latter are far higher than that of the former (Figure 5d). UHMOF-100 has by far recorded the highest water CA of approximately $176^{\circ}$ and this is evident from Table 1. UHMOF-100-spray-coated polymeric hydrophobic membrane (UHMOF-100/PDMS/PP) was exploited in oil-water separation (Scheme 1), with substantial oil hexadecane, crude oil, toluene, biodiesel, and $\mathrm{CCl}_{4}$. The absorption capacities ranged from $40 \mathrm{wt} . \%$ to $70 \mathrm{wt} . \%$ with negligible difference in absorption capacities even after 10 cycles. Again, when water-in-oil emulsions prepared from dichloromethane, toluene and hexadecane were each poured on the upper side of UHMOF-100/PDMS/PP, emulsion droplets instantly demulsified. Oil components permeated right away through the membrane retaining water wholly above the membrane. It also proved efficient in alcohol-water separation by showing a sharp contrast between alcohol sorption isotherms and that of water. The performance of this MOF is partially attributed to unsaturated copper open metal sites and guest-accessible voids (Figure $5 \mathrm{c}$ ). 
a)

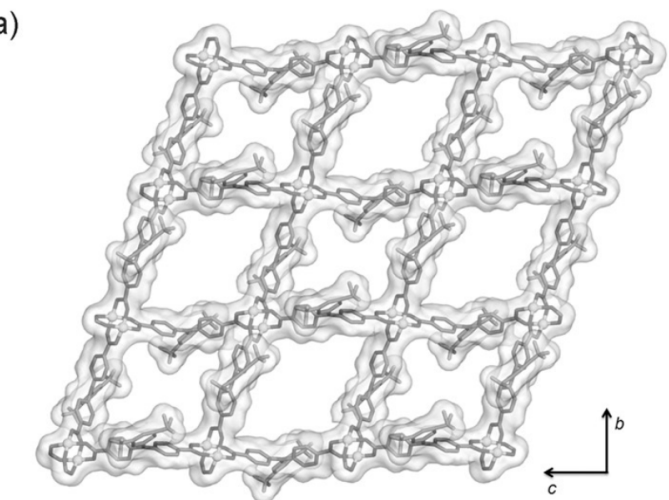

c)

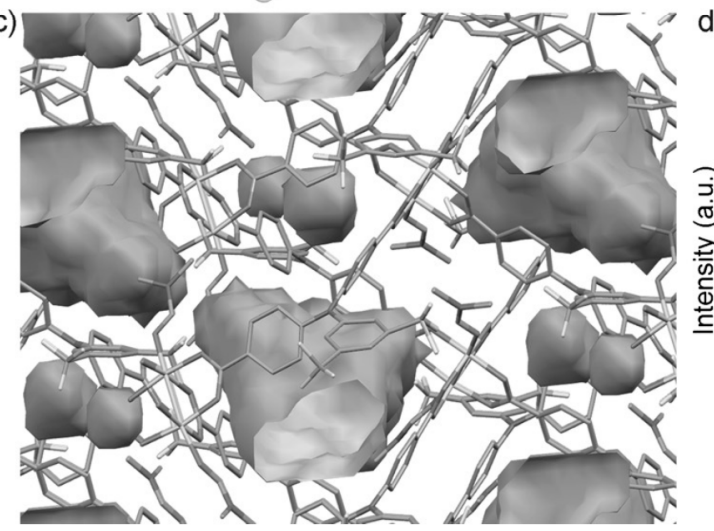

b)

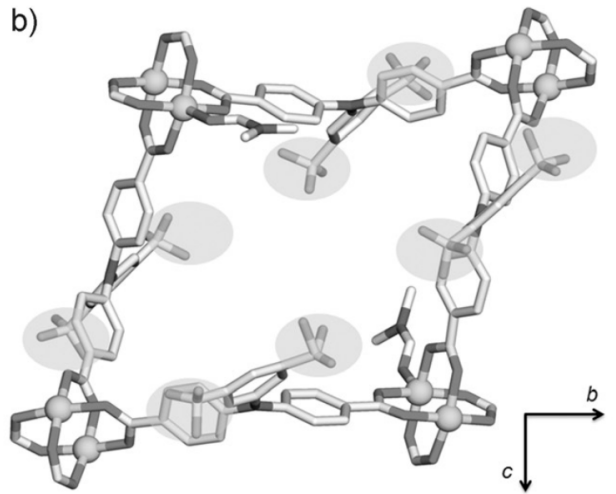

d)

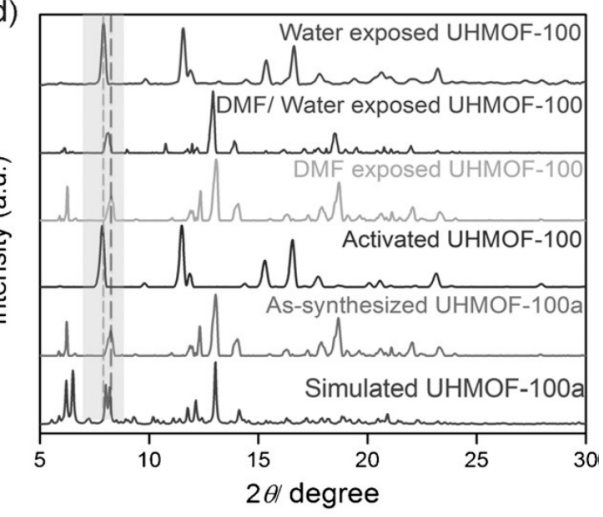

Figure 5. (a) Orthographic surface view of as-synthesized UHMOF-100 a; and (b) a single fluorous pores of UHMOF-100; (c) decorated fluorous voids on the Connolly surface; (d) PXRD profiles for different phases of UHMOF-100, validating its soft porous crystallinity and water stability. Reprinted with permission [32] Copyright 2016, Wiley-VCH.

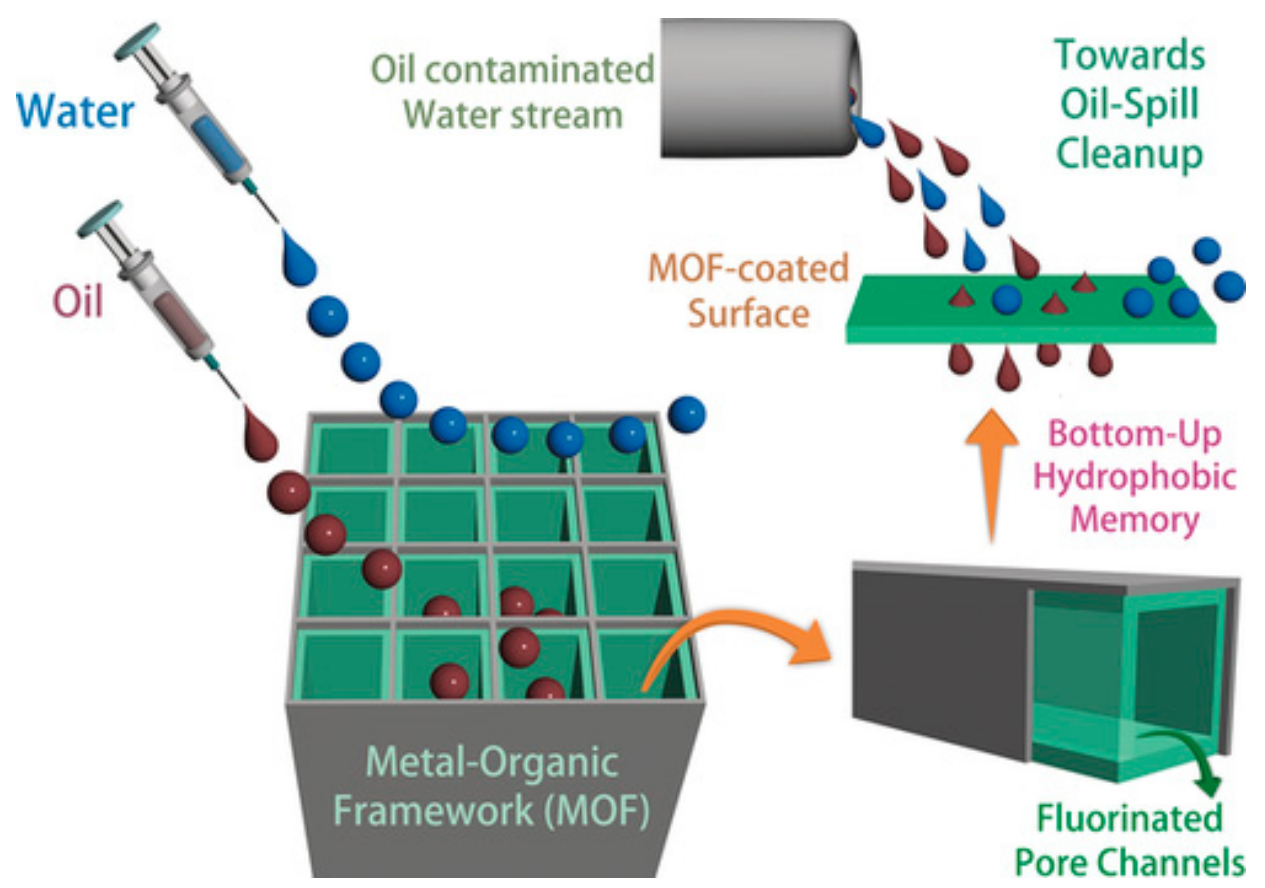

Scheme 1. Schematic illustration of fluorinated linker-based predesigned pore surface corrugations exploited as a potential method to obtain ultrahydrophobicity in MOFs. Reprinted with permission [32] Copyright 2016, Wiley-VCH. 
Modification of the external surface of zirconium-based MOFs via a facile method as shown in Scheme 2 through the incorporation of n-octadecylphosphonic acid (long alkyl chains) was performed by Ma et al. [62]. One important objective of this work was to impart hydrophobicity on the MOFs without the intact structure and internal channel environment being adjusted. It resulted in a superhydrophobic MOF of CA above $150^{\circ}$, was also used for oil-water and alcohol-water separation and absorbed up to about $99 \%$ of oil from oil-water mixture (Figure $3 b$ ).
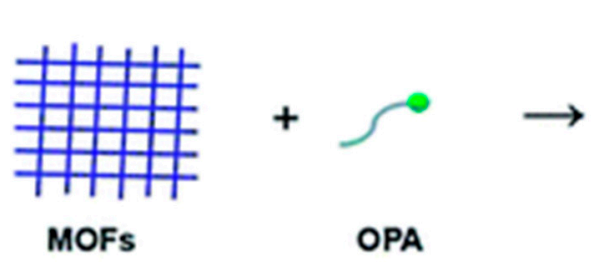

OPA
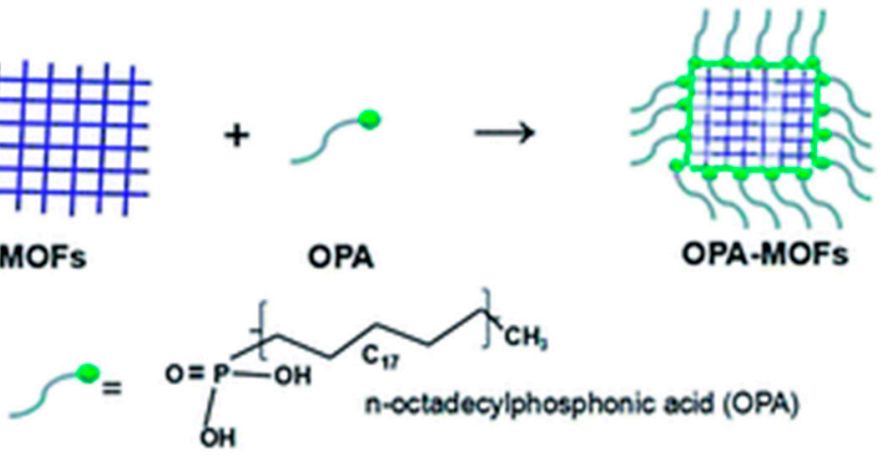

Scheme 2. Molecular-level external modification for superhydrophobic MOFs using OPA. Reprinted with permission [62] Copyright 2017, Royal Society of Chemistry.

Again, obtaining hydrophobic MOFs by coating the MOF surface with hydrophobic polymer crystals is inappropriate for this application. The reason is that these layers interact weakly with the water and do not promote water droplets from spreading on its surface [42]. The use of hydrophobic organic linkers in synthesis usually results in low surface area MOFs and is very evident in UHMOF-100 with BET of $469.2 \mathrm{~m}^{2} \cdot \mathrm{g}^{-1}$. UHMOF-100 showed the highest efficiency for crude oil but the reverse was true for UPC-21 MOF. OPA-UiO-66 performed a better methanol adsorption than the fluorinated ZIF-90 MOF. Toluene performed much better with OPA-UiO-66 than UHMOF-100. The alcohol removal percentage with fluorinated ZIF-90 increased with a decrease in polarity of adsorbate. These interesting observations reiterate that the methods used for the synthesis of the hydrophobic MOFs were effective for their respective applications; varying materials and methods yield varying specific results upon application.

\section{Gas Separation and Storage}

Gas separation and storage has been one strong application area for MOFs as a whole. The metal clusters linked by organic ligands in MOFs yields porous three-dimensional networks with large pore volumes, high surface areas, low densities, good thermal stability, controlled porosities and the possibility of adjusting the pore size and chemical compositions [72-75]. These properties make this class of materials highly suitable for gas separation and storage [76-79]. Adsorption selectivity and uptake capacity are the most important for gas separation purposes [80]. The separation of various gases is an essential industrial process [81-85] because of the high quality and purity requirements for their practical use [86-90]. Again, carbon dioxide is a greenhouse gas that needs to be reduced in the atmosphere to avoid the dramatic consequences of global warming. Increased surface area, pore size, and moisture stability of MOFs are the most efficient approaches to maximize $\mathrm{CO}_{2}$ uptake [91,92]. Hydrophobic MOFs promise to be of highly valuable use in this rather broad area because of their structural stability in moist environments.

The UPC-21 hydrophobic MOF synthesized by the Sun group was also tested for separation of gases $\left(C_{1}-C_{3}\right)$. It was found to compete with other MOFs for acetylene uptake especially [93] and other light hydrocarbons. It takes up to $196.5 \mathrm{~cm}^{3} \mathrm{~g}^{-1}$ at $273 \mathrm{~K}$ and $139.5 \mathrm{~cm}^{3} \mathrm{~g}^{-1}$ at $295 \mathrm{~K}$ of acetylene [65]. Moreover, it has a good uptake performance for other light hydrocarbons such as $\mathrm{C}_{2} \mathrm{H}_{4}, \mathrm{C}_{2} \mathrm{H}_{6}, \mathrm{C}_{3} \mathrm{H}_{6}$ and $\mathrm{C}_{3} \mathrm{H}_{8}$ at $273 \mathrm{~K}$ and 1 bar, values being 123.1, 137.6, 124.1 and $116.2 \mathrm{~cm}^{3} \mathrm{~g}^{-1}$ respectively (Figure 6). In comparison with other promising MOFs such as UTSA-67a [94] and Cu(etz) [95], UPC-21 has a 
higher uptake for light hydrocarbons $\left(\mathrm{C}_{2}-\mathrm{C}_{3}\right)$. Again, it is of great importance to note that UPC-21 displays much higher selectivity for $\mathrm{C}_{2} \mathrm{H}_{6} / \mathrm{CH}_{4}$ at $295 \mathrm{~K}$ (Figure 7) than the previously reported MOFs. The high density of open $\mathrm{Cu}$ (II) sites, optimized pore size, and multi-aromatic rings are the main contributions to its advantage over other MOFs in this application area [65].

(a)
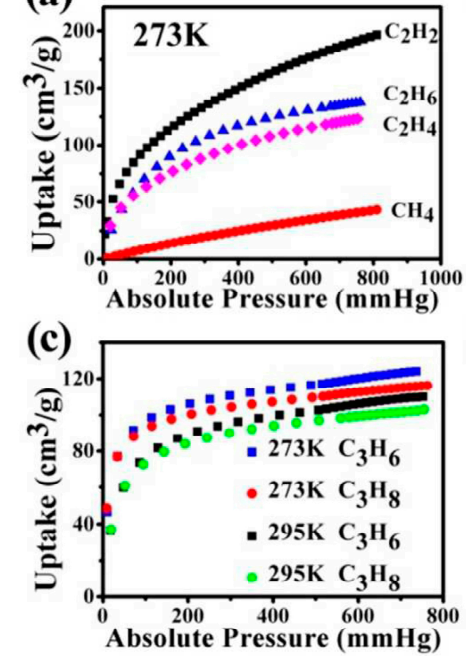
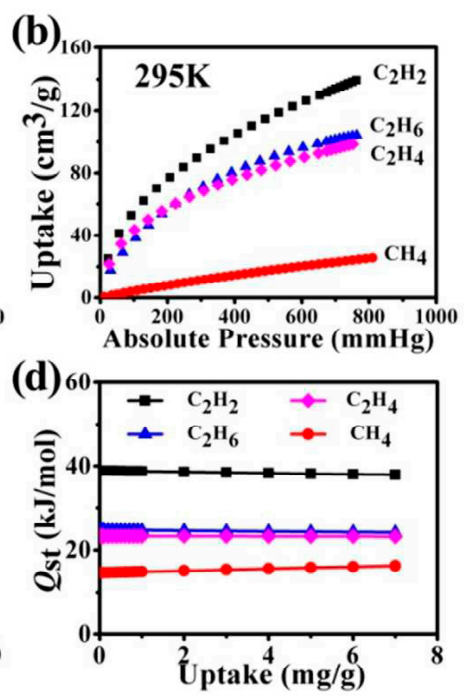

Figure 6. Hydrocarbon adsorption of UPC-21. The $\mathrm{C}_{2} \mathrm{H}_{2}, \mathrm{C}_{2} \mathrm{H}_{4}, \mathrm{C}_{2} \mathrm{H}_{6}$ and $\mathrm{CH}_{4}$ adsorption isotherms for UPC-21 at $273 \mathrm{~K}(\mathbf{a})$; and $295 \mathrm{~K}(\mathbf{b})$; (c) The $\mathrm{C}_{3} \mathrm{H}_{6}$ and $\mathrm{C}_{3} \mathrm{H}_{8}$ adsorption isotherms for UPC-21 at $273 \mathrm{~K}$ and $295 \mathrm{~K}$; (d) The isosteric heat of adsorption for $\mathrm{C}_{2} \mathrm{H}_{2}, \mathrm{C}_{2} \mathrm{H}_{4}, \mathrm{C}_{2} \mathrm{H}_{6}$ and $\mathrm{CH}_{4}$ Reprinted with permission [65] Copyright 2016, Royal Society of Chemistry.
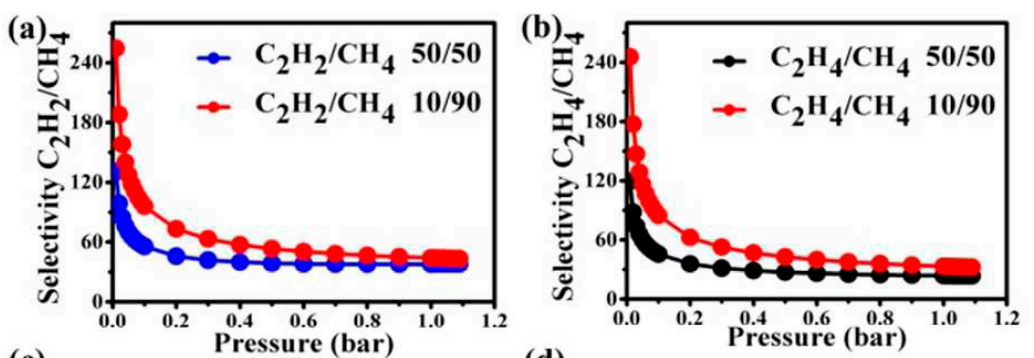

(c)

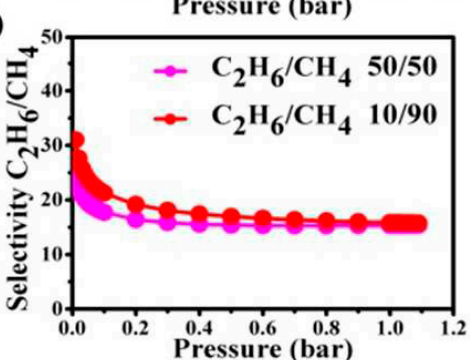

(d)

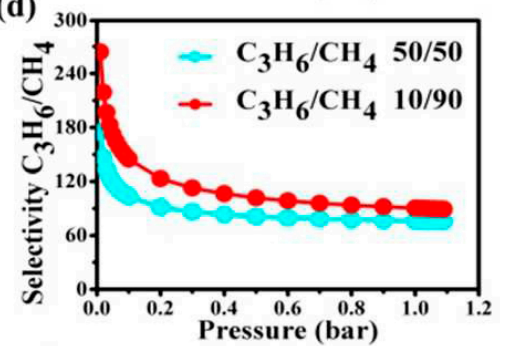

(e)

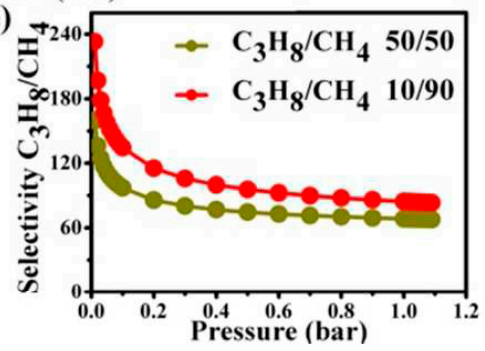

Figure 7. Selective adsorption of UPC-21. The calculations of the ideal adsorbed solution theory (IAST) selectivities for mixtures of $\mathrm{C}_{2} \mathrm{H}_{2} / \mathrm{CH}_{4}(\mathbf{a}) ; \mathrm{C}_{2} \mathrm{H}_{4} / \mathrm{CH}_{4}(\mathbf{b}) ; \mathrm{C}_{2} \mathrm{H}_{6} / \mathrm{CH}_{4}(\mathbf{c}) ; \mathrm{C}_{3} \mathrm{H}_{6} / \mathrm{CH}_{4}(\mathbf{d}) ; \mathrm{C}_{3} \mathrm{H}_{8} / \mathrm{CH}_{4}$ (e) at 295 K. Reprinted with permission [65] Copyright 2016, Royal Society of Chemistry. 
Considering the capture of $\mathrm{CO}_{2}$ from flue gas, a major requirement is that the incoming gas stream is dehydrated since water can bring about a noticeable reduction in the $\mathrm{CO}_{2}$ sorption capabilities [96-98]. Coating MOF surfaces with a hydrophobic polymer to render them water-resistant was recently illustrated by Qian et al. via a facile solution-immersion process [66]. The approach was attempted on three representative water-sensitive MOFs: $\mathrm{NH}_{2}$-MIL-125(Ti), ZIF-67 and HKUST-1 to prove its universality. The MOFs were coated with organosilicon, (DC 1-2577), depositing a layer of hydrophobic high molecular polymer on its external surface, not deeply penetrating the internal pores of the MOFs. The resulting MOFs retained their crystal structure, morphology and surface area when exposed to liquid water, and with a water CA of $146^{\circ}$. The surface hydrophobic MOFs retained up to about $86 \%$ of their $\mathrm{CO}_{2}$ sorption and desorption capabilities after being exposed to water, while that of the as-synthesized MOFs is about $21 \%$. Scanning Electron Microscope (SEM) images shown in Figure 8 give further proof of the stability of the coated MOFs in water.
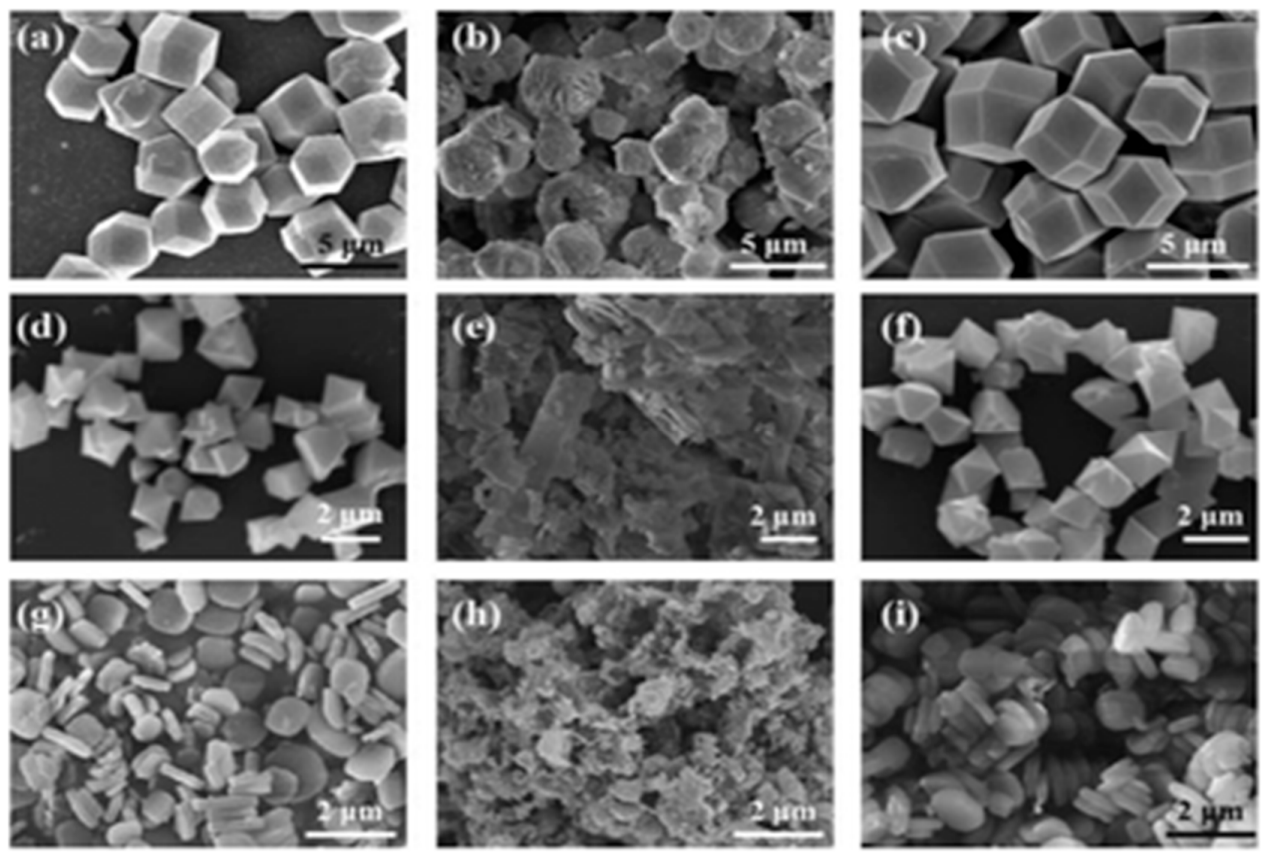

Figure 8. SEM images of (a) the AS ZIF-67, (b,c) the AS ZIF-67 and SH ZIF-67 after exposure to water for 5 days, respectively, (d) the AS HKUST-1, (e,f) the AS HKUST-1 and SH HKUST-1 after exposure to water for 5 days, respectively, (g) the AS NH N $_{2}$ MIL-125(Ti), (h,i) the AS NH$-M I L-125$ (Ti) and SH $\mathrm{NH}_{2}$-MIL-125(Ti) after exposure to water for 5 days, respectively. Reprinted with permission [66] Copyright 2017, Royal Society of Chemistry.

Moreover, a group of other scientists with the approach of facile vapor deposition technique, by polydimethylsiloxane (PDMS)-coating treatment [99], made hydrophobic MOFs that were suitable for $\mathrm{CO}_{2}$ sorption [29]. PDMS forms a thin protective hydrophobic surface layer on the MOFs, aiding in the retention of the crystalline structures and high porosity under moisture conditions. XRD patterns, BET values and $\mathrm{N}_{2}$ sorption isotherms of the coated MOFs remain relatively same after exposure to moisture. However, the original representative water-sensitive MOFs reported otherwise in all cases.

Again, water-stable, zinc-doped Zeolitic Imidazolate Framework-67 (ZIF-67) was synthesized for $\mathrm{CO}_{2}$ capture applications [100]. The water stability of ZIF-67 was enhanced by facile Zn-doping during the crystallization process. The MOF exhibited a far better stability in terms of crystal structure, morphology, $\mathrm{CO}_{2}$ uptake capacity and surface area as compared to the undoped MOF. This study realized a new approach to improve the water stability of MOFs and a more proper retention ability when exposed to moist environments. 
A bridging ligand strategy was used to prepare polyMOFs that were found to be suitable for $\mathrm{CO}_{2} / \mathrm{N}_{2}$ separations [28]. This is because the material reported relatively high $\mathrm{CO}_{2}$ sorption but very low $\mathrm{N}_{2}$ sorption. The exceptional water stability exhibited by these materials is attributed to the hydrophobicity of polymer ligands and cross-linking of the polymer chains within the MOFs. The following strategies form the bedrock upon which this method was derived. Some earlier reports prepared polymer MOF hybrid materials through PSM, whereby chemical cross-linking of the MOF is achieved through organic ligands to form polymeric monoliths [101-103]. Polymerization of polymer chains conducted inside the channels of MOFs has been another approach to synthesizing hybrids of MOFs and polymers [104-106].

In addition, a group of researchers has reported a new strategy to divide MOF open channels into confined and hydrophobic compartments by in situ polymerization [107-109] of aromatic acetylenes [110]. It was executed by adsorption and encapsulation of 1,2-diethynlybenzene (DEB) monomer into MOF-5 and further heating to a higher temperature to afford polynaphthylene (PN) into the inner channels via Bergman cyclization and subsequent radical polymerization. The resulting MOF, named PN@MOF-5 exhibited a significantly improved moisture stability, doubled $\mathrm{CO}_{2}$ capacity (78 vs. $38 \mathrm{~cm}^{3} / \mathrm{g}$ at $273 \mathrm{~K}$ and 1 bar) and 23 times higher $\mathrm{CO}_{2} / \mathrm{N}_{2}$ selectivity (212 vs. 9) compared with the pristine MOF-5.

With reference to recent literature, hydrophobic MOFs have been more extensively applied in $\mathrm{CO}_{2}$ capture in the broad area of gas separation and storage. Such works have re-visited old ways or invented new strategies of synthesizing hydrophobic MOFs for such a purpose. Among them, creating a permeable hydrophobic layer on the surface of MOFs is the commonest strategy. This strategy has the advantage of avoiding setbacks such as reduced porosity, tedious procedure, complex instrumentation, and so on. Again, intrinsic properties such as surface area, pore texture, and crystalline structure are retained. Using a hydrophobic organic ligand realizes lower surface area compared to the other methods, including the in situ polymerization method. The $\mathrm{CO}_{2}$ sorption retention capacities of the hydrophobic MOFs made by the vapor deposition method was much higher (at least $96 \%$ ) than those of the solution-immersion method (at least $76 \%$ ), after exposure to moisture. These results may not be solely based on the processes adopted but the ligands and MOFs experimented with as well.

\section{Other Applications}

\subsection{Self-Cleaning}

The function of removing contaminating particles from superhydrophobic surfaces by impacting or rolling water droplets is denoted as self-cleaning [111]. This phenomenon requires external forces such as gravity and is typically referred to as "Lotus Effect" [112,113]. Micro and nanoscale surface roughness, which reduces surface free energy is a prerequisite for such surfaces to exhibit water repellence behavior [114-118]. The guideline for the design of synthetic self-cleaning materials entails size, shape, rigidity and ordering with combined surface micro and nanostructure [119-122]. Aligned polymer nanofibers [123-125], self-assembled monolayer (SAM) modified surfaces [126,127], carbon nanotubes (CNTs) [128,129] and lithographic patterning [130-133] with very high CAs have been successfully designed. MOFs would definitely present the benefit of inherent porosity and water surface repellence $[43,134-144]$.

NMOF-1 is a hydrophobic MOF that has been tested for the self-cleaning application [64]. It was synthesized via coordination directed self-assembly of dialkoxyoctadecyl-oligo-(p-phenyleneethynylene) dicarboxylate (OPE-C18) with Zinc II in DMF/ $\mathrm{H}_{2} 0$ mixture. This strategy was adapted from an earlier reported work [27]. OPE- $\mathrm{C}_{18}$, being a hydrophobic alkyl chain when exposed on the MOF surface, decreased surface energy hence increasing hydrophobicity. NMOF-1 is thermally stable in that the characteristic PXRD peaks are retained even at temperatures as high as $300^{\circ} \mathrm{C}$. A glass surface was coated with the MOF, dust particles placed on it and water droplets introduced on the surface. The water droplets in no time rolled off the surface laden with the dust particles (Figure 9). This phenomenon depicts the 
self-cleaning nature of NMOF-1. Field Emission Scanning Electron Microscopy (FESEM) and Atomic Force Microscopy (AFM) jointly confirmed the hierarchal surface roughness nature of NMOF-1, trapped with air pockets (Figure 10). This is the main property of this MOF that contributes to its superhydrophobicity and subsequently its self-cleaning ability. This work realized MOF with a very high CA and corrosion resistance with a $\mathrm{pH}$ stability range of 1-9. This makes it a promising material for industrial applications in stain-resistant textiles, anti-biofouling paints in ships and so on.
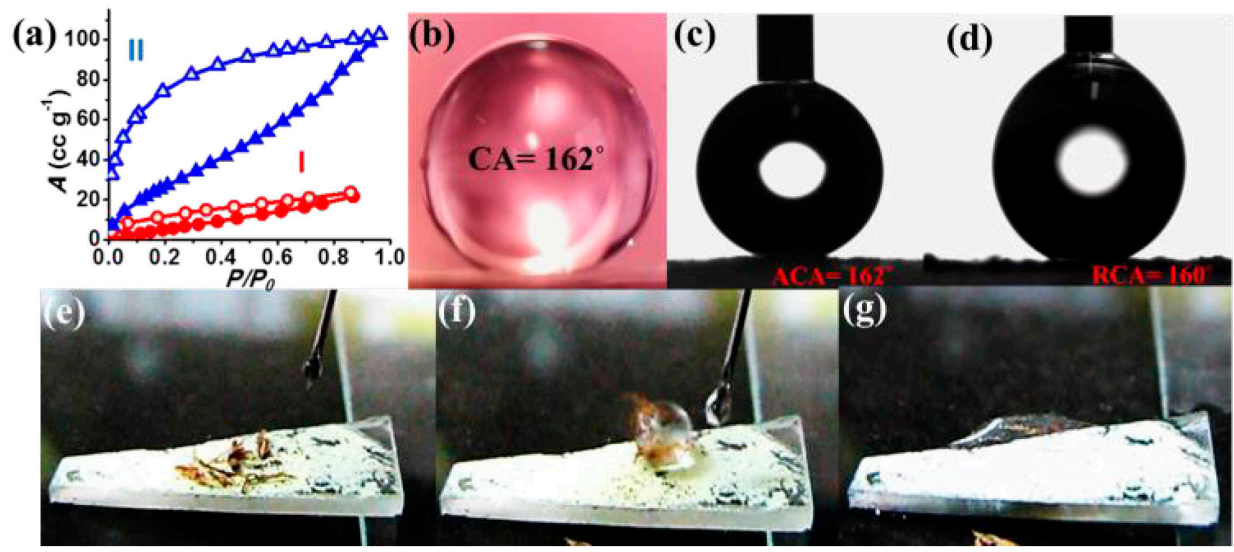

Figure 9. (a) Solvent vapor adsorption isotherms of NMOF- at $298 \mathrm{~K}$ : I: Water (red) and II: benzene (blue), Po is the saturated vapor pressure, $3.17 \mathrm{kPa}$ (water) and $12.60 \mathrm{kPa}$ (Benzene) at $298 \mathrm{~K}$. Water contact angles of NMOF-1 coated substrate; (b) Static contact angle; (c) advancing contact angle and (d) receding contact angle (e-g) video snapshots of a self-cleaning experiment showing the removal of dirt from the surface. Reprinted with permission [64] Copyright 2015, Royal Society of Chemistry.
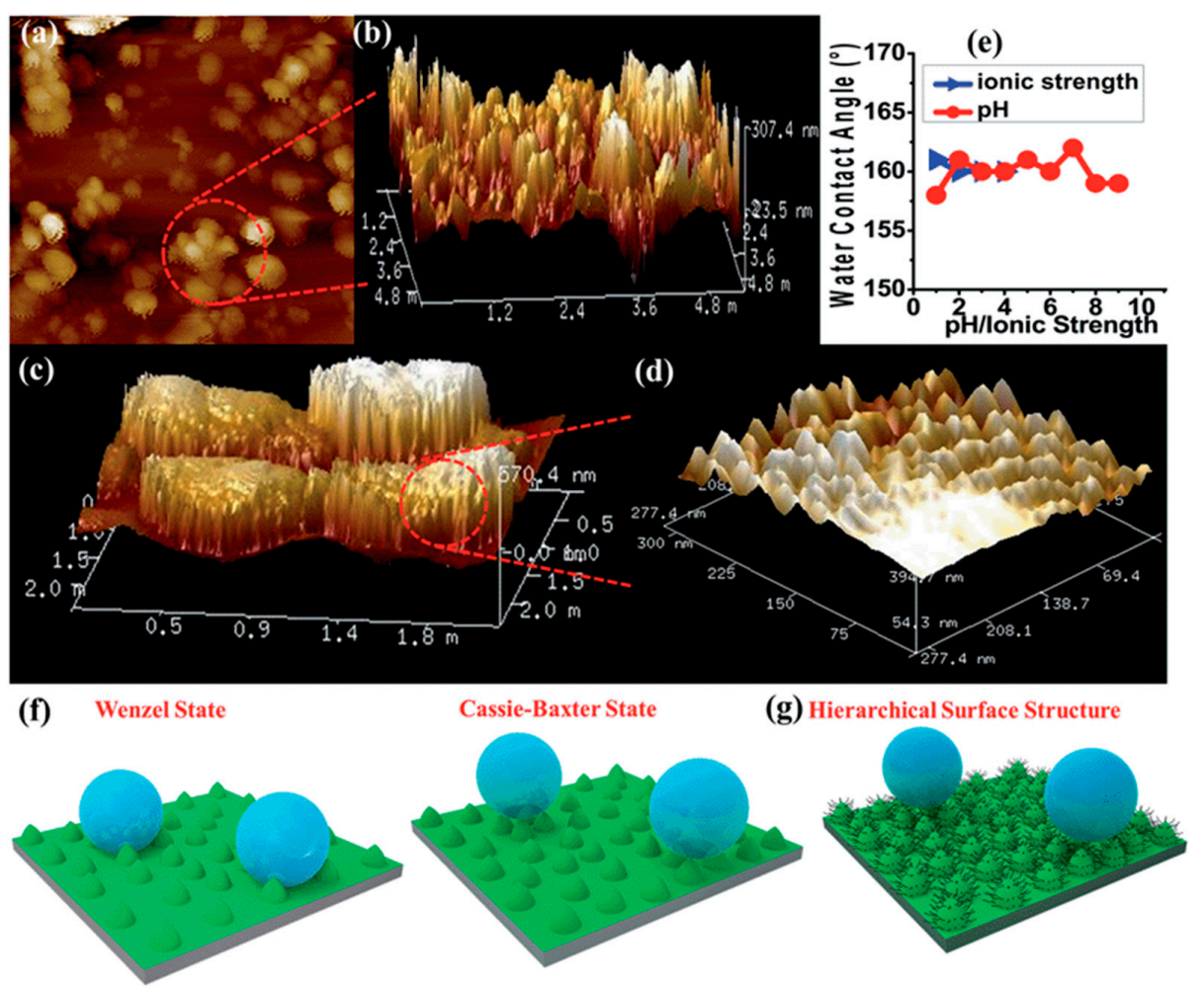

Figure 10. (a) 2D-AFM image of NMOF-1 micro-particles on coated glass surface; (b) Corresponding 3D-AFM; (c) 3D-AFM image of four adjacent microspheres of NMOF-1; (d) Corresponding high magnified image showing continuous nano-roughness present on each micro-particle (e) Plots showing changes in $\mathrm{CA}$ with $\mathrm{pH}$ /ionic strength; (f) Schematic showing the different states use to explain surface 
water repellency: left: Wenzel state or the wetting state, right: Cassie-Baxter state or the superhydrophobic state (A transition from the Wenzel to the Cassie-Baxter model occurs when we consider that rough textures on a surface trap air pockets in between); (g) Incorporation of hierarchical surface for the generation of the self-cleaning effect in NMOF-1. Reprinted with permission [64] Copyright 2015 Royal Society of Chemistry.

\subsection{Liquid Marbles}

A less common application area for hydrophobic MOFs is liquid marbles. Liquid marble is a ball-like object formed by virtue of a liquid being entirely encapsulated in a hydrophobic powder [145]. Liquid marbles have functioned as miniature reactors [146], micro-pumps [147], $\mathrm{pH}$ sensors [148], gas sensors [149] and water pollution sensors [150]. Several hydrophobic particles such as superhydrophobic silica aerogels and $\mathrm{Fe}_{3} \mathrm{O}_{4}$ have been explored in this field but least can be said of hydrophobic MOFs. The perfluorooctyl-modified $\mathrm{NH}_{2}$-MIL-53(Al) developed by Chin et al. turned out highly hydrophobic and was used to make liquid marbles [151]. Interfacial polymerization of ethyl-2-cyanoacrylate was further carried out on the outer surface of the marbles to produce stable liquid capsules (Figure 11). This work revealed that this approach to interfacial polymerization can be used industrially for the economical formation of biodegradable liquid capsules.

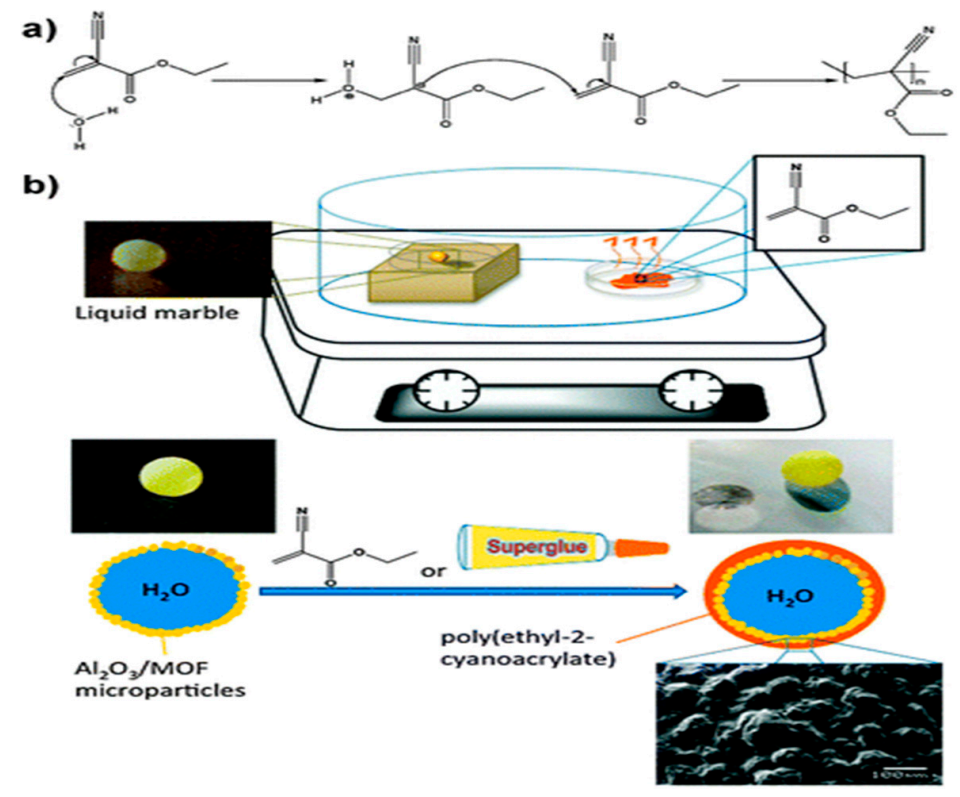

Figure 11. (a) Mechanism of cyanoacrylate polymerization; (b) Reaction set-up for the interfacial polymerization of ethyl-2-cyanoacrylate on a liquid marble. Heating the hotplate to $80^{\circ} \mathrm{C}$ enhances vaporization of the monomer, which condenses on the liquid marble and polymerizes. Reprinted with permission [151] Copyright 2013 Royal Society of Chemistry.

Liquid marbles have broadly served as micro-reactors for polymerization [152] and other reactions [146]. Their property of low adhesion to surfaces makes them act well as non-wetting liquid droplets that display various dynamic characteristics; liquid droplets can be manipulated. MOFs being materials with several advantages can make a significant contribution to the liquid marbles story.

\section{Summary and Outlook}

This review has given a concise update on the recent applications of hydrophobic MOFs in general. The research on hydrophobic MOFs began about a decade ago and just like any other material explored in science, they come with their imperfections. The evolution of this special kind of MOFs came about as scientists attempted to solve the chemical and thermal instability nature of most MOFs, as they were known to be mostly moisture-instable. Scientists managed to solve this particular 
problem and obviously produced new application areas for MOFs, which is a very recommendable achievement. However, scientists should produce water-stable MOFs that are still applicable to the removal of contaminants in wastewater other than oils as this is the main advantage activated carbon has over MOFs.

One major application area of hydrophobic MOFs is in oil-water separation and most of these MOFs can do just that. Researchers should then move to the next step of developing hydrophobic MOFs that can further separate these oils into the various classes of hydrocarbons, which is a more successful recovery of oils. We think that designing MOFs with specific pore sizes would be a stepping stone to overcoming this problem. The advantage is that for their practical use, these hydrocarbons are required at high quality and purity.

Furthermore, the application areas of hydrophobic MOFs as it stands now are limited; an area such as catalysis, if explored, will bring about an unrecoverable revolution in hydrophobic MOFs. In an area such as the Fischer-Tropsch Synthesis, it is thought that hydrophobicity can partially suppress water-gas shift reaction and ultimately decrease carbon dioxide production; hydrophobic MOFs could be of use here. Again, we recommend researchers to study the areas of liquid marbles and self-cleaning more. Moreover, it is recommended that researchers look at applying hydrophobic MOFs whose applications are yet to be explored. This is likely to reveal some major setbacks in designing and synthesizing hydrophobic MOFs, bringing about more novel methods of producing hydrophobic MOFs that have lesser and lesser disadvantages in the various application fields.

MOFs find themselves in a vast area of application in physics, biology, chemistry, engineering and so on. The untiring collaboration of scientists from a plethora of fields will achieve endless solutions to problems in the society.

Author Contributions: R.A.-B. did the compilation and writing; H.L. did the supervision.

Funding: This research was funded by National Natural Science Foundation of China, grant number 21303177.

Acknowledgments: The authors thank the financial support of the National Natural Science Foundation of China (Grant no. 21303177).

Conflicts of Interest: The authors declare no conflict of interest.

\section{References}

1. Zhu, H.; Zhang, Q.; Zhu, S. Assembly of a Metal-Organic Framework into 3 D Hierarchical Porous Monoliths Using a Pickering High Internal Phase Emulsion Template. Chem. A Eur. J. 2016, 22, 8751-8755. [CrossRef] [PubMed]

2. Liu, H.; Zhu, H.; Zhu, S. Reversibly Dispersible/Collectable Metal-Organic Frameworks Prepared by Grafting Thermally Responsive and Switchable Polymers. Macromol. Mater. Eng. 2015, 300, 191-197. [CrossRef]

3. Furukawa, H.; Cordova, K.E.; O'Keeffe, M.; Yaghi, O.M. The Chemistry and Applications of Metal-Organic Frameworks. Science 2013, 341. [CrossRef] [PubMed]

4. Ma, S.; Zhou, H.-C. Gas storage in porous metal-organic frameworks for clean energy applications. Chem. Commun. 2010, 46, 44-53. [CrossRef] [PubMed]

5. Sibo, W.; Xinchen, W. Multifunctional Metal-Organic Frameworks for Photocatalysis. Small 2015, 11, 3097-3112. [CrossRef]

6. Hasan, Z.; Jhung, S.H. Removal of hazardous organics from water using metal-organic frameworks (MOFs): Plausible mechanisms for selective adsorptions. J. Hazard. Mater. 2015, 283, 329-339. [CrossRef] [PubMed]

7. Meek, S.T.; Greathouse, J.A.; Allendorf, M.D. Metal-Organic Frameworks: A Rapidly Growing Class of Versatile Nanoporous Materials. Adv. Mater. 2011, 23, 249-267. [CrossRef] [PubMed]

8. Pang, J.; Jiang, F.; Wu, M.; Liu, C.; Su, K.; Lu, W.; Yuan, D.; Hong, M. A porous metal-organic framework with ultrahigh acetylene uptake capacity under ambient conditions. Nat. Commun. 2015, 6, 7575. [CrossRef] [PubMed]

9. Farha, O.K.; Özgür Yazaydın, A.; Eryazici, I.; Malliakas, C.D.; Hauser, B.G.; Kanatzidis, M.G.; Nguyen, S.T.; Snurr, R.Q.; Hupp, J.T. De novo synthesis of a metal-organic framework material featuring ultrahigh surface area and gas storage capacities. Nat. Chem. 2010, 2, 944. [CrossRef] [PubMed] 
10. Zhu, H.; Liu, H.; Zhitomirsky, I.; Zhu, S. Preparation of metal-organic framework films by electrophoretic deposition method. Mater. Lett. 2015, 142, 19-22. [CrossRef]

11. Chen, B.; Liang, C.; Yang, J.; Contreras, D.S.; Clancy, Y.L.; Lobkovsky, E.B.; Yaghi, O.M.; Dai, S. A Microporous Metal-Organic Framework for Gas-Chromatographic Separation of Alkanes. Angew. Chem. Int. Ed. 2006, 45, 1390-1393. [CrossRef] [PubMed]

12. Bae, T.-H.; Lee, J.S.; Qiu, W.; Koros, W.J.; Jones, C.W.; Nair, S. A High-Performance Gas-Separation Membrane Containing Submicrometer-Sized Metal-Organic Framework Crystals. Angew. Chem. 2010, 122, 10059-10062. [CrossRef]

13. Hamon, L.; Llewellyn, P.L.; Devic, T.; Ghoufi, A.; Clet, G.; Guillerm, V.; Pirngruber, G.D.; Maurin, G.; Serre, C.; Driver, G.; et al. Co-adsorption and Separation of $\mathrm{CO}_{2}-\mathrm{CH}_{4}$ Mixtures in the Highly Flexible MIL-53(Cr) MOF. J. Am. Chem. Soc. 2009, 131, 17490-17499. [CrossRef] [PubMed]

14. Liu, J.; Sun, F.; Zhang, F.; Wang, Z.; Zhang, R.; Wang, C.; Qiu, S. In situ growth of continuous thin metal-organic framework film for capacitive humidity sensing. J. Mater. Chem. 2011, 21, 3775-3778. [CrossRef]

15. Stassen, I.; Burtch, N.; Talin, A.; Falcaro, P.; Allendorf, M.; Ameloot, R. An updated roadmap for the integration of metal-organic frameworks with electronic devices and chemical sensors. Chem. Soc. Rev. 2017, 46, 3185-3241. [CrossRef] [PubMed]

16. Mondloch, J.E.; Katz, M.J.; Isley Iii, W.C.; Ghosh, P.; Liao, P.; Bury, W.; Wagner, G.W.; Hall, M.G.; DeCoste, J.B.; Peterson, G.W.; et al. Destruction of chemical warfare agents using metal-organic frameworks. Nat. Mater. 2015, 14, 512-516. [CrossRef] [PubMed]

17. Corma, A.; García, H.; Llabrés i Xamena, F.X. Engineering Metal Organic Frameworks for Heterogeneous Catalysis. Chem. Rev. 2010, 110, 4606-4655. [CrossRef] [PubMed]

18. Lee, J.; Farha, O.K.; Roberts, J.; Scheidt, K.A.; Nguyen, S.T.; Hupp, J.T. Metal-organic framework materials as catalysts. Chem. Soc. Rev. 2009, 38, 1450-1459. [CrossRef] [PubMed]

19. Shultz, A.M.; Farha, O.K.; Hupp, J.T.; Nguyen, S.T. A Catalytically Active, Permanently Microporous MOF with Metalloporphyrin Struts. J. Am. Chem. Soc. 2009, 131, 4204-4205. [CrossRef] [PubMed]

20. Rogge, S.M.; Bavykina, A.; Hajek, J.; Garcia, H.; Olivos-Suarez, A.I.; Sepúlveda-Escribano, A.; Vimont, A.; Clet, G.; Bazin, P.; Kapteijn, F. Metal-organic and covalent organic frameworks as single-site catalysts. Chem. Soc. Rev. 2017, 46, 3134-3184. [CrossRef] [PubMed]

21. Zhang, X.; Gao, Y.; Liu, H.; Liu, Z. Fabrication of porous metal-organic frameworks via a mixed-ligand strategy for highly selective and efficient dye adsorption in aqueous solution. Cryst. Eng. Comm. 2015, 17, 6037-6043. [CrossRef]

22. Shimizu, G.K.H.; Taylor, J.M.; Kim, S. Proton Conduction with Metal-Organic Frameworks. Science 2013, 341, 354-355. [CrossRef] [PubMed]

23. Horcajada, P.; Chalati, T.; Serre, C.; Gillet, B.; Sebrie, C.; Baati, T.; Eubank, J.F.; Heurtaux, D.; Clayette, P.; Kreuz, C.; et al. Porous metal-organic-framework nanoscale carriers as a potential platform for drug delivery and imaging. Nat. Mater. 2010, 9, 172-178. [CrossRef] [PubMed]

24. Canivet, J.; Fateeva, A.; Guo, Y.; Coasne, B.; Farrusseng, D. Water adsorption in MOFs: Fundamentals and applications. Chem. Soc. Rev. 2014, 43, 5594-5617. [CrossRef] [PubMed]

25. Low, J.J.; Benin, A.I.; Jakubczak, P.; Abrahamian, J.F.; Faheem, S.A.; Willis, R.R. Virtual High Throughput Screening Confirmed Experimentally: Porous Coordination Polymer Hydration. J. Am. Chem. Soc. 2009, 131, 15834-15842. [CrossRef] [PubMed]

26. Kolleboyina, J.; Ramanatha, D.K.K.; Christoph, R.; Martin, P.; Michal, O.; Radek, Z.; Fischer, R.A. Biomimetic Superhydrophobic/Superoleophilic Highly Fluorinated Graphene Oxide and ZIF-8 Composites for Oil-Water Separation. Angew. Chem. Int. Ed. 2016, 55, 1178-1182. [CrossRef]

27. Prabhakara, R.K.; Masakazu, H.; Kenji, S.; Shuhei, F.; Jingui, D.; Susumu, K. Design of Superhydrophobic Porous Coordination Polymers through the Introduction of External Surface Corrugation by the Use of an Aromatic Hydrocarbon Building Unit. Angew. Chem. 2014, 126, 8364-8369. [CrossRef]

28. Zhang, Z.; Nguyen, H.T.H.; Miller, S.A.; Ploskonka, A.M.; DeCoste, J.B.; Cohen, S.M. Polymer-Metal-Organic Frameworks (polyMOFs) as Water Tolerant Materials for Selective Carbon Dioxide Separations. J. Am. Chem. Soc. 2016, 138, 920-925. [CrossRef] [PubMed] 
29. Zhang, W.; Hu, Y.; Ge, J.; Jiang, H.-L.; Yu, S.-H. A Facile and General Coating Approach to Moisture/Water-Resistant Metal-Organic Frameworks with Intact Porosity. J. Am. Chem. Soc. 2014, 136, 16978-16981. [CrossRef] [PubMed]

30. Nguyen, J.G.; Cohen, S.M. Moisture-Resistant and Superhydrophobic Metal-Organic Frameworks Obtained via Postsynthetic Modification. J. Am. Chem. Soc. 2010, 132, 4560-4561. [CrossRef] [PubMed]

31. Chen, T.-H.; Popov, I.; Zenasni, O.; Daugulis, O.; Miljanic, O.S. Superhydrophobic perfluorinated metal-organic frameworks. Chem. Commun. 2013, 49, 6846-6848. [CrossRef] [PubMed]

32. Mukherjee, S.; Kansara, A.M.; Saha, D.; Gonnade, R.; Mullangi, D.; Manna, B.; Desai, A.V.; Thorat, S.H.; Singh, P.S.; Mukherjee, A.; et al. An Ultrahydrophobic Fluorous Metal-Organic Framework Derived Recyclable Composite as a Promising Platform to Tackle Marine Oil Spills. Chem. A Eur. J. 2016, 22, 10937-10943. [CrossRef] [PubMed]

33. Rodríguez-Hermida, S.; Tsang, M.Y.; Vignatti, C.; Stylianou, K.C.; Guillerm, V.; Pérez-Carvajal, J.; Teixidor, F.; Viñas, C.; Choquesillo-Lazarte, D.; Verdugo-Escamilla, C. Switchable Surface Hydrophobicity-Hydrophilicity of a Metal-Organic Framework. Angew. Chem. Int. Ed. 2016, 55, 16049-16053. [CrossRef] [PubMed]

34. Bae, J.; Lee, E.J.; Jeong, N.C. Metal coordination and metal activation abilities of commonly unreactive chloromethanes toward metal-organic frameworks. Chem. Commun. 2018, 54, 6458-6471. [CrossRef] [PubMed]

35. Bae, J.; Choi, J.S.; Hwang, S.; Yun, W.S.; Song, D.; Lee, J.; Jeong, N.C. Multiple Coordination Exchanges for Room-Temperature Activation of Open-Metal Sites in Metal-Organic Frameworks. ACS Appl. Mater. Interfaces 2017, 9, 24743-24752. [CrossRef] [PubMed]

36. Choi, J.S.; Bae, J.; Lee, E.J.; Jeong, N.C. A Chemical Role for Trichloromethane: Room-Temperature Removal of Coordinated Solvents from Open Metal Sites in the Copper-Based Metal-Organic Frameworks. Inorg. Chem. 2018, 57, 5225-5231. [CrossRef] [PubMed]

37. Nelson, A.P.; Farha, O.K.; Mulfort, K.L.; Hupp, J.T. Supercritical processing as a route to high internal surface areas and permanent microporosity in metal-organic framework materials. J. Am. Chem. Soc. 2008, 131, 458-460. [CrossRef] [PubMed]

38. Tsao, C.-S.; Chen, C.-Y.; Chung, T.-Y.; Su, C.-J.; Su, C.-H.; Chen, H.-L.; Jeng, U.-S.; Yu, M.-S.; Liao, P.-Y.; Lin, K.-F. Structural Analysis and Thermal Behavior of Pore Networks in High-Surface-Area Metal-Organic Framework. J. Phys. Chem. C 2010, 114, 7014-7020. [CrossRef]

39. Yang, Y.; Shukla, P.; Wang, S.; Rudolph, V.; Chen, X.-M.; Zhu, Z. Significant improvement of surface area and $\mathrm{CO}_{2}$ adsorption of $\mathrm{Cu}-\mathrm{BTC}$ via solvent exchange activation. RSC Adv. 2013, 3, 17065-17072. [CrossRef]

40. Cohen, S.M. Postsynthetic Methods for the Functionalization of Metal-Organic Frameworks. Chem. Rev. 2012, 112, 970-1000. [CrossRef] [PubMed]

41. Wang, Z.; Cohen, S.M. Postsynthetic modification of metal-organic frameworks. Chem. Soc. Rev. 2009, 38, 1315-1329. [CrossRef] [PubMed]

42. Cohen, S.M. Modifying MOFs: New chemistry, new materials. Chem. Sci. 2010, 1, 32-36. [CrossRef]

43. Tanabe, K.K.; Cohen, S.M. Postsynthetic modification of metal-organic frameworks-A progress report. Chem. Soc. Rev. 2011, 40, 498-519. [CrossRef] [PubMed]

44. Turner, J.A. A realizable renewable energy future. Science 1999, 285, 687-689. [CrossRef] [PubMed]

45. Li, A.; Sun, H.-X.; Tan, D.-Z.; Fan, W.-J.; Wen, S.-H.; Qing, X.-J.; Li, G.-X.; Li, S.-Y.; Deng, W.-Q. Superhydrophobic conjugated microporous polymers for separation and adsorption. Energy Environ. Sci. 2011, 4, 2062-2065. [CrossRef]

46. Pollard, S.J.T.; Fowler, G.D.; Sollars, C.J.; Perry, R. Low-cost adsorbents for waste and wastewater treatment: A review. Sci. Total Environ. 1992, 116, 31-52. [CrossRef]

47. Ono, T.; Sugimoto, T.; Shinkai, S.; Sada, K. Lipophilic polyelectrolyte gels as super-absorbent polymers for nonpolar organic solvents. Nat. Mater. 2007, 6, 429. [CrossRef] [PubMed]

48. Zhang, K.; Lively, R.P.; Noel, J.D.; Dose, M.E.; McCool, B.A.; Chance, R.R.; Koros, W.J. Adsorption of water and ethanol in MFI-type zeolites. Langmuir 2012, 28, 8664-8673. [CrossRef] [PubMed]

49. Zhang, K.; Lively, R.P.; Dose, M.E.; Li, L.; Koros, W.J.; Ruthven, D.M.; McCool, B.A.; Chance, R.R. Diffusion of water and ethanol in silicalite crystals synthesized in fluoride media. Microporous Mesoporous Mater. 2013, 170, 259-265. [CrossRef] 
50. Zhang, K.; Lively, R.P.; Dose, M.E.; Brown, A.J.; Zhang, C.; Chung, J.; Nair, S.; Koros, W.J.; Chance, R.R. Alcohol and water adsorption in zeolitic imidazolate frameworks. Chem. Commun. 2013, 49, 3245-3247. [CrossRef] [PubMed]

51. Zhang, K.; Gupta, K.M.; Chen, Y.; Jiang, J. Biofuel purification in GME zeolitic-imidazolate frameworks: From ab initio calculations to molecular simulations. AIChE J. 2015, 61, 2763-2775. [CrossRef]

52. Yao, X.; Song, Y.; Jiang, L. Applications of bio-inspired special wettable surfaces. Adv. Mater. 2011, 23, 719-734. [CrossRef] [PubMed]

53. Wang, B.; Liang, W.; Guo, Z.; Liu, W. Biomimetic super-lyophobic and super-lyophilic materials applied for oil/water separation: A new strategy beyond nature. Chem. Soc. Rev. 2015, 44, 336-361. [CrossRef] [PubMed]

54. Jiang, T.; Guo, Z.; Liu, W. Biomimetic superoleophobic surfaces: focusing on their fabrication and applications. J. Mater. Chem. A 2015, 3, 1811-1827. [CrossRef]

55. Adebajo, M.O.; Frost, R.L.; Kloprogge, J.T.; Carmody, O.; Kokot, S. Porous materials for oil spill cleanup: A review of synthesis and absorbing properties. J. Porous Mater. 2003, 10, 159-170. [CrossRef]

56. Hayase, G.; Kanamori, K.; Hasegawa, G.; Maeno, A.; Kaji, H.; Nakanishi, K. A superamphiphobic macroporous silicone monolith with marshmallow-like flexibility. Angew. Chem. Int. Ed. 2013, 52, 10788-10791. [CrossRef] [PubMed]

57. Zhang, L.; Zhang, Z.; Wang, P. Smart surfaces with switchable superoleophilicity and superoleophobicity in aqueous media: Toward controllable oil/water separation. NPG Asia Mater. 2012, 4, e8. [CrossRef]

58. Zhang, J.; Seeger, S. Polyester materials with superwetting silicone nanofilaments for oil/water separation and selective oil absorption. Adv. Funct. Mater. 2011, 21, 4699-4704. [CrossRef]

59. Gui, X.; Wei, J.; Wang, K.; Cao, A.; Zhu, H.; Jia, Y.; Shu, Q.; Wu, D. Carbon nanotube sponges. Adv. Mater. 2010, 22, 617-621. [CrossRef] [PubMed]

60. Sohn, K.; Na, Y.J.; Chang, H.; Roh, K.-M.; Jang, H.D.; Huang, J. Oil absorbing graphene capsules by capillary molding. Chem. Commun. 2012, 48, 5968-5970. [CrossRef] [PubMed]

61. Feng, L.; Zhang, Z.; Mai, Z.; Ma, Y.; Liu, B.; Jiang, L.; Zhu, D. A Super-Hydrophobic and Super-Oleophilic Coating Mesh Film for the Separation of Oil and Water. Angew. Chem. Int. Ed. 2004, 43, 2012-2014. [CrossRef] [PubMed]

62. Sun, Y.; Sun, Q.; Huang, H.; Aguila, B.; Niu, Z.; Perman, J.A.; Ma, S. A molecular-level superhydrophobic external surface to improve the stability of metal-organic frameworks. J. Mater. Chem. A 2017, 5, 18770-18776. [CrossRef]

63. Liu, C.; Liu, Q.; Huang, A. A superhydrophobic zeolitic imidazolate framework (ZIF-90) with high steam stability for efficient recovery of bioalcohols. Chem. Commun. 2016, 52, 3400-3402. [CrossRef] [PubMed]

64. Roy, S.; Suresh, V.M.; Maji, T.K. Self-cleaning MOF: Realization of extreme water repellence in coordination driven self-assembled nanostructures. Chem. Sci. 2016, 7, 2251-2256. [CrossRef] [PubMed]

65. Zhang, M.; Xin, X.; Xiao, Z.; Wang, R.; Zhang, L.; Sun, D. A multi-aromatic hydrocarbon unit induced hydrophobic metal-organic framework for efficient C2/C1 hydrocarbon and oil/water separation. J. Mater. Chem. A 2017, 5, 1168-1175. [CrossRef]

66. Qian, X.; Sun, F.; Sun, J.; Wu, H.; Xiao, F.; Wu, X.; Zhu, G. Imparting surface hydrophobicity to metal-organic frameworks using a facile solution-immersion process to enhance water stability for $\mathrm{CO}_{2}$ capture. Nanoscale 2017, 9, 2003-2008. [CrossRef] [PubMed]

67. Modena, M.M.; Wang, Y.; Riedel, D.; Burg, T.P. Resolution enhancement of suspended microchannel resonators for weighing of biomolecular complexes in solution. Lab Chip 2014, 14, 342-350. [CrossRef] [PubMed]

68. Modena, M.M.; Hirschle, P.; Wuttke, S.; Burg, T.P. Mass Measurements Reveal Preferential Sorption of Mixed Solvent Components in Porous Nanoparticles. Small 2018, 1800826. [CrossRef] [PubMed]

69. Wuttke, S.; Dietl, C.; Hinterholzinger, F.M.; Hintz, H.; Langhals, H.; Bein, T. Turn-on fluorescence triggered by selective internal dye replacement in MOFs. Chem. Commun. 2014, 50, 3599-3601. [CrossRef] [PubMed]

70. Wilmer, C.E.; Leaf, M.; Lee, C.Y.; Farha, O.K.; Hauser, B.G.; Hupp, J.T.; Snurr, R.Q. Large-scale screening of hypothetical metal-organic frameworks. Nat. Chem. 2011, 4, 83. [CrossRef] [PubMed]

71. Schnobrich, J.K.; Lebel, O.; Cychosz, K.A.; Dailly, A.; Wong-Foy, A.G.; Matzger, A.J. Linker-Directed Vertex Desymmetrization for the Production of Coordination Polymers with High Porosity. J. Am. Chem. Soc. 2010, 132, 13941-13948. [CrossRef] [PubMed] 
72. Qian, X.; Yadian, B.; Wu, R.; Long, Y.; Zhou, K.; Zhu, B.; Huang, Y. Structure stability of metal-organic framework MIL-53 (Al) in aqueous solutions. Int. J. Hydrog. Energy 2013, 38, 16710-16715. [CrossRef]

73. Qian, X.; Zhong, Z.; Yadian, B.; Wu, J.; Zhou, K.; Teo, J.S.-K.; Chen, L.; Long, Y.; Huang, Y. Loading MIL-53 (Al) with Ag nanoparticles: Synthesis, structural stability and catalytic properties. Int. J. Hydrog. Energy 2014, 39, 14496-14502. [CrossRef]

74. Cui, C.; Liu, Y.; Xu, H.; Li, S.; Zhang, W.; Cui, P.; Huo, F. Self-Assembled Metal-Organic Frameworks Crystals for Chemical Vapor Sensing. Small 2014, 10, 3672-3676. [CrossRef] [PubMed]

75. Wu, R.; Qian, X.; Law, A.W.-K.; Zhou, K. Coordination polymer-derived mesoporous $\mathrm{Co}_{3} \mathrm{O}_{4}$ hollow nanospheres for high-performance lithium-ions batteries. RSC Adv. 2016, 6, 50846-50850. [CrossRef]

76. Lu, G.; Cui, C.; Zhang, W.; Liu, Y.; Huo, F. Synthesis and Self-Assembly of Monodispersed Metal-Organic Framework Microcrystals. Chem. Asian J. 2013, 8, 69-72. [CrossRef] [PubMed]

77. Cadiau, A.; Adil, K.; Bhatt, P.; Belmabkhout, Y.; Eddaoudi, M. A metal-organic framework-based splitter for separating propylene from propane. Science 2016, 353, 137-140. [CrossRef] [PubMed]

78. Zhang, C.; Zhao, Y.; Li, Y.; Zhang, X.; Chi, L.; Lu, G. Defect-Controlled Preparation of UiO-66 Metal-Organic Framework Thin Films with Molecular Sieving Capability. Chem. Asian J. 2016, 11, 207-210. [CrossRef] [PubMed]

79. Zhang, B.; Zhang, J.; Han, B. Assembling Metal-Organic Frameworks in Ionic Liquids and Supercritical $\mathrm{CO}_{2}$. Chem. Asian J. 2016, 11, 2610-2619. [CrossRef] [PubMed]

80. Wen, H.-M.; Wang, H.; Li, B.; Cui, Y.; Wang, H.; Qian, G.; Chen, B. A microporous metal-organic framework with lewis basic nitrogen sites for high $\mathrm{C}_{2} \mathrm{H}_{2}$ storage and significantly enhanced $\mathrm{C}_{2} \mathrm{H}_{2} / \mathrm{CO}_{2}$ separation at ambient conditions. Inorg. Chem. 2016, 55, 7214-7218. [CrossRef] [PubMed]

81. Chen, Z.; Adil, K.; Weseliński, Ł.J.; Belmabkhout, Y.; Eddaoudi, M. A supermolecular building layer approach for gas separation and storage applications: The eea and rtl MOF platforms for $\mathrm{CO}_{2}$ capture and hydrocarbon separation. J. Mater. Chem. A 2015, 3, 6276-6281. [CrossRef]

82. Xue, D.-X.; Belmabkhout, Y.; Shekhah, O.; Jiang, H.; Adil, K.; Cairns, A.J.; Eddaoudi, M. Tunable rare earth fcu-MOF platform: Access to adsorption kinetics driven gas/vapor separations via pore size contraction. J. Am. Chem. Soc. 2015, 137, 5034-5040. [CrossRef] [PubMed]

83. Xu, H.; He, Y.; Zhang, Z.; Xiang, S.; Cai, J.; Cui, Y.; Yang, Y.; Qian, G.; Chen, B. A microporous metal-organic framework with both open metal and Lewis basic pyridyl sites for highly selective $\mathrm{C}_{2} \mathrm{H}_{2} / \mathrm{CH}_{4}$ and $\mathrm{C}_{2} \mathrm{H}_{2} / \mathrm{CO}_{2}$ gas separation at room temperature. J. Mater. Chem. A 2013, 1,77-81. [CrossRef]

84. Yang, S.; Ramirez-Cuesta, A.J.; Newby, R.; Garcia-Sakai, V.; Manuel, P.; Callear, S.K.; Campbell, S.I.; Tang, C.C.; Schröder, M. Supramolecular binding and separation of hydrocarbons within a functionalized porous metal-organic framework. Nat. Chem. 2014, 7, 121. [CrossRef] [PubMed]

85. Duan, J.; Jin, W.; Kitagawa, S. Water-resistant porous coordination polymers for gas separation. Coord. Chem. Rev. 2017, 332, 48-74. [CrossRef]

86. Luebke, R.; Belmabkhout, Y.; Weseliński, Ł.J.; Cairns, A.J.; Alkordi, M.; Norton, G.; Wojtas, Ł.; Adil, K.; Eddaoudi, M. Versatile rare earth hexanuclear clusters for the design and synthesis of highly-connected ftw-MOFs. Chem. Sci. 2015, 6, 4095-4102. [CrossRef] [PubMed]

87. Assen, A.H.; Belmabkhout, Y.; Adil, K.; Bhatt, P.M.; Xue, D.X.; Jiang, H.; Eddaoudi, M. Ultra-Tuning of the Rare-Earth fcu-MOF Aperture Size for Selective Molecular Exclusion of Branched Paraffins. Angew. Chem. Int. Ed. 2015, 54, 14353-14358. [CrossRef] [PubMed]

88. Cai, J.; Yu, J.; Wang, H.; Duan, X.; Zhang, Q.; Wu, C.; Cui, Y.; Yu, Y.; Wang, Z.; Chen, B. A Noninterpenetrated Metal-Organic Framework Built from an Enlarged Tetracarboxylic Acid for Small Hydrocarbon Separation. Cryst. Growth Des. 2015, 15, 4071-4074. [CrossRef]

89. Wen, H.-M.; Li, B.; Wang, H.; Wu, C.; Alfooty, K.; Krishna, R.; Chen, B. A microporous metal-organic framework with rare lvt topology for highly selective $\mathrm{C}_{2} \mathrm{H}_{2} / \mathrm{C}_{2} \mathrm{H}_{4}$ separation at room temperature. Chem. Commun. 2015, 51, 5610-5613. [CrossRef] [PubMed]

90. Zhang, Z.; Xiang, S.; Rao, X.; Zheng, Q.; Fronczek, F.R.; Qian, G.; Chen, B. A rod packing microporous metal-organic framework with open metal sites for selective guest sorption and sensing of nitrobenzene. Chem. Commun. 2010, 46, 7205-7207. [CrossRef] [PubMed]

91. Millward, A.R.; Yaghi, O.M. Metal-organic frameworks with exceptionally high capacity for storage of carbon dioxide at room temperature. J. Am. Chem. Soc. 2005, 127, 17998-17999. [CrossRef] [PubMed] 
92. Furukawa, H.; Ko, N.; Go, Y.B.; Aratani, N.; Choi, S.B.; Choi, E.; Yazaydin, A.Ö.; Snurr, R.Q.; O’Keeffe, M.; Kim, J. Ultrahigh porosity in metal-organic frameworks. Science 2010, 329, 424-428. [CrossRef] [PubMed]

93. Hu, Y.; Xiang, S.; Zhang, W.; Zhang, Z.; Wang, L.; Bai, J.; Chen, B. A new MOF-505 analog exhibiting high acetylene storage. Chem. Commun. 2009, 48, 7551-7553. [CrossRef] [PubMed]

94. Wen, H.-M.; Li, B.; Wang, H.; Krishna, R.; Chen, B. High acetylene/ethylene separation in a microporous zinc(ii) metal-organic framework with low binding energy. Chem. Commun. 2016, 52, 1166-1169. [CrossRef] [PubMed]

95. Zhang, J.-P.; Chen, X.-M. Optimized Acetylene/Carbon Dioxide Sorption in a Dynamic Porous Crystal. J. Am. Chem. Soc. 2009, 131, 5516-5521. [CrossRef] [PubMed]

96. Liu, J.; Tian, J.; Thallapally, P.K.; McGrail, B.P. Selective $\mathrm{CO}_{2}$ Capture from Flue Gas Using Metal-Organic Frameworks-A Fixed Bed Study. J. Phys. Chem. C 2012, 116, 9575-9581. [CrossRef]

97. Kizzie, A.C.; Wong-Foy, A.G.; Matzger, A.J. Effect of Humidity on the Performance of Microporous Coordination Polymers as Adsorbents for $\mathrm{CO}_{2}$ Capture. Langmuir 2011, 27, 6368-6373. [CrossRef] [PubMed]

98. Burtch, N.C.; Jasuja, H.; Walton, K.S. Water Stability and Adsorption in Metal-Organic Frameworks. Chem. Rev. 2014, 114, 10575-10612. [CrossRef] [PubMed]

99. Yuan, J.; Liu, X.; Akbulut, O.; Hu, J.; Suib, S.L.; Kong, J.; Stellacci, F. Superwetting nanowire membranes for selective absorption. Nat. Nanotechnol. 2008, 3, 332. [CrossRef] [PubMed]

100. Qian, X.; Ren, Q.; Wu, X.; Sun, J.; Wu, H.; Lei, J. Enhanced Water Stability in Zn-Doped Zeolitic Imidazolate Framework-67 (ZIF-67) for $\mathrm{CO}_{2}$ Capture Applications. Chem. Sel. 2018, 3, 657-661. [CrossRef]

101. Furukawa, Y.; Ishiwata, T.; Sugikawa, K.; Kokado, K.; Sada, K. Nano-and Microsized Cubic Gel Particles from Cyclodextrin Metal-Organic Frameworks. Angew. Chem. 2012, 124, 10718-10721. [CrossRef]

102. Tsotsalas, M.; Liu, J.; Tettmann, B.; Grosjean, S.; Shahnas, A.; Wang, Z.; Azucena, C.; Addicoat, M.; Heine, T.; Lahann, J. Fabrication of highly uniform gel coatings by the conversion of surface-anchored metal-organic frameworks. J. Am. Chem. Soc. 2013, 136, 8-11. [CrossRef] [PubMed]

103. Ishiwata, T.; Furukawa, Y.; Sugikawa, K.; Kokado, K.; Sada, K. Transformation of metal-organic framework to polymer gel by cross-linking the organic ligands preorganized in metal-organic framework. J. Am. Chem. Soc. 2013, 135, 5427-5432. [CrossRef] [PubMed]

104. Uemura, T.; Kaseda, T.; Kitagawa, S. Controlled synthesis of anisotropic polymer particles templated by porous coordination polymers. Chem. Mater. 2013, 25, 3772-3776. [CrossRef]

105. Distefano, G.; Suzuki, H.; Tsujimoto, M.; Isoda, S.; Bracco, S.; Comotti, A.; Sozzani, P.; Uemura, T.; Kitagawa, S. Highly ordered alignment of a vinyl polymer by host-guest cross-polymerization. Nat. Chem. 2013, 5, 335. [CrossRef] [PubMed]

106. Park, I.H.; Medishetty, R.; Lee, H.H.; Mulijanto, C.E.; Quah, H.S.; Lee, S.S.; Vittal, J.J. Formation of a Syndiotactic Organic Polymer Inside a MOF by a [2 + 2] Photo-Polymerization Reaction. Angew. Chem. Int. Ed. 2015, 54, 7313-7317. [CrossRef] [PubMed]

107. Uemura, T.; Kitaura, R.; Ohta, Y.; Nagaoka, M.; Kitagawa, S. Nanochannel-promoted polymerization of substituted acetylenes in porous coordination polymers. Angew. Chem. Int. Ed. 2006, 45, 4112-4116. [CrossRef] [PubMed]

108. Uemura, T.; Hiramatsu, D.; Kubota, Y.; Takata, M.; Kitagawa, S. Topotactic linear radical polymerization of divinylbenzenes in porous coordination polymers. Angew. Chem. Int. Ed. 2007, 46, 4987-4990. [CrossRef] [PubMed]

109. Uemura, T.; Yanai, N.; Kitagawa, S. Polymerization reactions in porous coordination polymers. Chem. Soc. Rev. 2009, 38, 1228-1236. [CrossRef] [PubMed]

110. Ding, N.; Li, H.; Feng, X.; Wang, Q.; Wang, S.; Ma, L.; Zhou, J.; Wang, B. Partitioning MOF-5 into confined and hydrophobic compartments for carbon capture under humid conditions. J. Am. Chem. Soc. 2016, 138, 10100-10103. [CrossRef] [PubMed]

111. Wisdom, K.M.; Watson, J.A.; Qu, X.; Liu, F.; Watson, G.S.; Chen, C.-H. Self-cleaning of superhydrophobic surfaces by self-propelled jumping condensate. Proc. Natl. Acad. Sci. USA 2013, 201210770. [CrossRef] [PubMed]

112. Blossey, R. Self-cleaning surfaces-Virtual realities. Nat. Mater. 2003, 2, 301. [CrossRef] [PubMed]

113. Zhang, J.; Wang, A.; Seeger, S. Nepenthes pitcher inspired anti-wetting silicone nanofilaments coatings: Preparation, unique anti-wetting and self-cleaning behaviors. Adv. Funct. Mater. 2014, 24, 1074-1080. [CrossRef] 
114. Li, X.-M.; Reinhoudt, D.; Crego-Calama, M. What do we need for a superhydrophobic surface? A review on the recent progress in the preparation of superhydrophobic surfaces. Chem. Soc. Rev. 2007, 36, 1350-1368. [CrossRef] [PubMed]

115. Liu, K.; Yao, X.; Jiang, L. Recent developments in bio-inspired special wettability. Chem. Soc. Rev. 2010, 39, 3240-3255. [CrossRef] [PubMed]

116. Roach, P.; Shirtcliffe, N.J.; Newton, M.I. Progess in superhydrophobic surface development. Soft Matter 2008, 4, 224-240. [CrossRef]

117. Sun, T.; Feng, L.; Gao, X.; Jiang, L. Bioinspired surfaces with special wettability. Acc. Chem. Res. 2005, 38, 644-652. [CrossRef] [PubMed]

118. Xin, B.; Hao, J. Reversibly switchable wettability. Chem. Soc. Rev. 2010, 39, 769-782. [CrossRef] [PubMed]

119. Tuteja, A.; Choi, W.; Ma, M.; Mabry, J.M.; Mazzella, S.A.; Rutledge, G.C.; McKinley, G.H.; Cohen, R.E. Designing superoleophobic surfaces. Science 2007, 318, 1618-1622. [CrossRef] [PubMed]

120. Dyett, B.P.; Wu, A.H.; Lamb, R.N. Mechanical Stability of Surface Architecture Consequences for Superhydrophobicity. ACS Appl. Mater. Interfaces 2014, 6, 18380-18394. [CrossRef] [PubMed]

121. Liu, T.; Kim, C.-J. Turning a surface superrepellent even to completely wetting liquids. Science 2014, 346, 1096-1100. [CrossRef] [PubMed]

122. Verho, T.; Bower, C.; Andrew, P.; Franssila, S.; Ikkala, O.; Ras, R.H. Mechanically durable superhydrophobic surfaces. Adv. Mater. 2011, 23, 673-678. [CrossRef] [PubMed]

123. Chiou, N.-R.; Lu, C.; Guan, J.; Lee, L.J.; Epstein, A.J. Growth and alignment of polyaniline nanofibres with superhydrophobic, superhydrophilic and other properties. Nat. Nanotechnol. 2007, 2, 354. [CrossRef] [PubMed]

124. Feng, L.; Li, S.; Li, H.; Zhai, J.; Song, Y.; Jiang, L.; Zhu, D. Super-hydrophobic surface of aligned polyacrylonitrile nanofibers. Angew. Chem. Int. Ed. 2002, 41, 1221-1223. [CrossRef]

125. Zahner, D.; Abagat, J.; Svec, F.; Fréchet, J.M.; Levkin, P.A. A facile approach to superhydrophilic-superhydrophobic patterns in porous polymer films. Adv. Mater. 2011, 23, 3030-3034. [CrossRef] [PubMed]

126. Belman, N.; Jin, K.; Golan, Y.; Israelachvili, J.N.; Pesika, N.S. Origin of the contact angle hysteresis of water on chemisorbed and physisorbed self-assembled monolayers. Langmuir 2012, 28, 14609-14617. [CrossRef] [PubMed]

127. Genzer, J.; Efimenko, K. Creating long-lived superhydrophobic polymer surfaces through mechanically assembled monolayers. Science 2000, 290, 2130-2133. [CrossRef] [PubMed]

128. Jung, Y.C.; Bhushan, B. Mechanically durable carbon nanotube-composite hierarchical structures with superhydrophobicity, self-cleaning, and low-drag. ACS Nano 2009, 3, 4155-4163. [CrossRef] [PubMed]

129. Dong, X.; Chen, J.; Ma, Y.; Wang, J.; Chan-Park, M.B.; Liu, X.; Wang, L.; Huang, W.; Chen, P. Superhydrophobic and superoleophilic hybrid foam of graphene and carbon nanotube for selective removal of oils or organic solvents from the surface of water. Chem. Commun. 2012, 48, 10660-10662. [CrossRef] [PubMed]

130. Kobaku, S.P.; Kota, A.K.; Lee, D.H.; Mabry, J.M.; Tuteja, A. Patterned Superomniphobic-Superomniphilic Surfaces: Templates for Site-Selective Self-Assembly. Angew. Chem. 2012, 124, 10256-10260. [CrossRef]

131. Geyer, F.L.; Ueda, E.; Liebel, U.; Grau, N.; Levkin, P.A. Superhydrophobic-superhydrophilic micropatterning: towards genome-on-a-chip cell microarrays. Angew. Chem. Int. Ed. 2011, 50, 8424-8427. [CrossRef] [PubMed]

132. Lai, Y.; Lin, C.; Wang, H.; Huang, J.; Zhuang, H.; Sun, L. Superhydrophilic-superhydrophobic micropattern on $\mathrm{TiO}_{2}$ nanotube films by photocatalytic lithography. Electrochem. Commun. 2008, 10, 387-391. [CrossRef]

133. Feng, J.; Tuominen, M.T.; Rothstein, J.P. Hierarchical superhydrophobic surfaces fabricated by dual-scale electron-beam-lithography with well-ordered secondary nanostructures. Adv. Funct. Mater. 2011, 21, 3715-3722. [CrossRef]

134. Maji, T.K.; Matsuda, R.; Kitagawa, S. A flexible interpenetrating coordination framework with a bimodal porous functionality. Nat. Mater. 2007, 6, 142. [CrossRef] [PubMed]

135. Li, H.; Eddaoudi, M.; O'Keeffe, M.; Yaghi, O.M. Design and synthesis of an exceptionally stable and highly porous metal-organic framework. Nature 1999, 402, 276. [CrossRef]

136. Kitagawa, S.; Kitaura, R.; Noro, S.I. Functional porous coordination polymers. Angew. Chem. Int. Ed. 2004, 43, 2334-2375. [CrossRef] [PubMed]

137. Herm, Z.R.; Wiers, B.M.; Mason, J.A.; van Baten, J.M.; Hudson, M.R.; Zajdel, P.; Brown, C.M.; Masciocchi, N.; Krishna, R.; Long, J.R. Separation of hexane isomers in a metal-organic framework with triangular channels. Science 2013, 340, 960-964. [CrossRef] [PubMed] 
138. Roy, S.; Chakraborty, A.; Maji, T.K. Lanthanide-organic frameworks for gas storage and as magneto-luminescent materials. Coord. Chem. Rev. 2014, 273, 139-164. [CrossRef]

139. Haldar, R.; Matsuda, R.; Kitagawa, S.; George, S.J.; Maji, T.K. Amine-Responsive Adaptable Nanospaces: Fluorescent Porous Coordination Polymer for Molecular Recognition. Angew. Chem. Int. Ed. 2014, 53, 11772-11777. [CrossRef] [PubMed]

140. Zhang, Z.; Nguyen, H.T.H.; Miller, S.A.; Cohen, S.M. PolyMOFs: A Class of Interconvertible Polymer-Metal-Organic-Framework Hybrid Materials. Angew. Chem. Int. Ed. 2015, 54, 6152-6157. [CrossRef] [PubMed]

141. Fischer, R.A. Meta-Organic Frameworks-The New Jack of All Trades for (Inorganic) Chemists. Angew. Chem. Int. Ed. 2014, 53, 5716-5717. [CrossRef] [PubMed]

142. Heine, J.; Müller-Buschbaum, K. Engineering metal-based luminescence in coordination polymers and metal-organic frameworks. Chem. Soc. Rev. 2013, 42, 9232-9242. [CrossRef] [PubMed]

143. Seo, Y.K.; Yoon, J.W.; Lee, J.S.; Hwang, Y.K.; Jun, C.H.; Chang, J.S.; Wuttke, S.; Bazin, P.; Vimont, A.; Daturi, M. Porous Materials: Energy-Efficient Dehumidification over Hierachically Porous Metal-Organic Frameworks as Advanced Water Adsorbents. Adv. Mater. 2012, 24, 710. [CrossRef]

144. He, Y.; Li, B.; O'Keeffe, M.; Chen, B. Multifunctional metal-organic frameworks constructed from meta-benzenedicarboxylate units. Chem. Soc. Rev. 2014, 43, 5618-5656. [CrossRef] [PubMed]

145. Aussillous, P.; Quéré, D. Liquid marbles. Nature 2001, 411, 924. [CrossRef] [PubMed]

146. Xue, Y.; Wang, H.; Zhao, Y.; Dai, L.; Feng, L.; Wang, X.; Lin, T. Magnetic Liquid Marbles: A "Precise" Miniature Reactor. Adv. Mater. 2010, 22, 4814-4818. [CrossRef] [PubMed]

147. Bormashenko, E.; Balter, R.; Aurbach, D. Micropump based on liquid marbles. Appl. Phys. Lett. 2010, 97, 091908. [CrossRef]

148. Fujii, S.; Kameyama, S.; Armes, S.P.; Dupin, D.; Suzaki, M.; Nakamura, Y. pH-responsive liquid marbles stabilized with poly(2-vinylpyridine) particles. Soft Matter 2010, 6, 635-640. [CrossRef]

149. Tian, J.; Arbatan, T.; Li, X.; Shen, W. Liquid marble for gas sensing. Chem. Commun. 2010, 46, 4734-4736. [CrossRef] [PubMed]

150. Bormashenko, E.; Musin, A. Revealing of water surface pollution with liquid marbles. Appl. Surf. Sci. 2009, 255, 6429-6431. [CrossRef]

151. Chin, J.M.; Reithofer, M.R.; Tan, T.T.Y.; Menon, A.G.; Chen, E.Y.; Chow, C.A.; Hor, A.T.S.; Xu, J. Supergluing MOF liquid marbles. Chem. Commun. 2013, 49, 493-495. [CrossRef] [PubMed]

152. Sheng, Y.; Sun, G.; Ngai, T. Dopamine polymerization in liquid marbles: A general route to Janus particle synthesis. Langmuir 2016, 32, 3122-3129. [CrossRef] [PubMed] 